Historic, Archive Document

Do not assume content reflects current scientific knowledge, policies, or practices. 


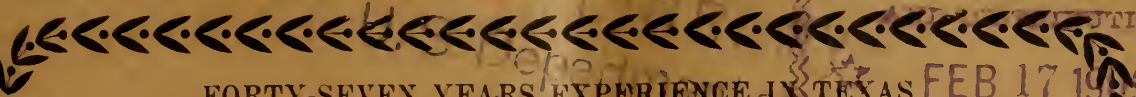

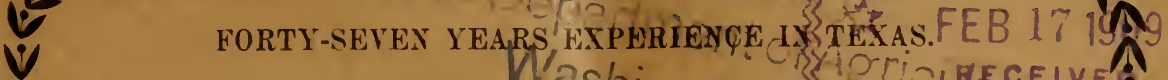

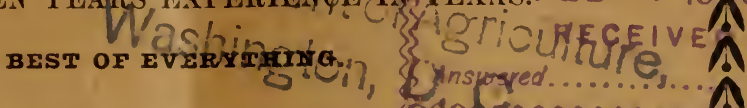

1908

CATALOGUE

$1909 \approx$

OF THE

$\hat{A}$

v

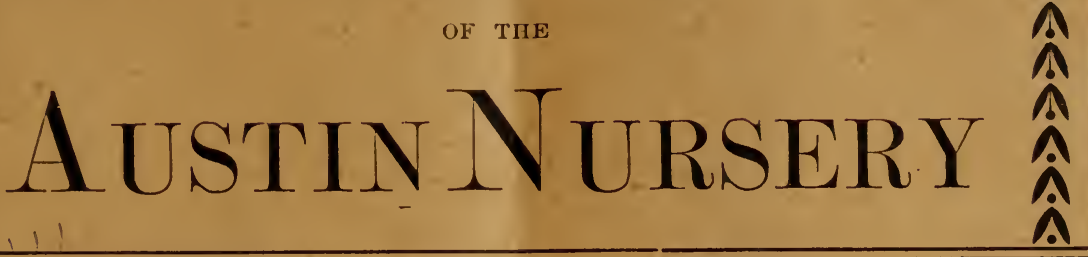

2 yr. old Gonzales Plum

5 foot Orchara Plour.
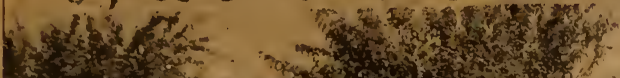

$$
\text { (2) }
$$


This is our Thirty-fourth Annual Catalogue and for the thirty-fourth time we thank the many who have favored us with their orders.

- Our ever increasing business assures us that our efforts have not been in vais, and with the wider experience, the better varieties we are constantly adding, and the thousands of orchards that constantly "talk" for us, we hope to reap some reward for the years of constant toil. Nothing gives me so much pleasure as the upbuilding of my nursery.

The Beautiful in nature attracts me more each year and I am increasing my ornamental department. I am acquiring the very best assortment, and if necessary I can suggest how to plant to obtain the most permanently pleasing effects.

\section{BUSINESS NOTICES.}

\begin{abstract}
Our Shipping Season begins about Norember 15th, and extends to April 1st.

Selection of Varieties-Except where particular varieties are wanted, it is a good idea to leave the selection to us, stating the general character of soil, situation, whether the fruit is wanted for market or home use, the desired time of ripening, etc. We are well acquainted with the requirements of the different sections of Texas, and no doubt in most instances can make a better selection than the customer himself. In some cases, when we can not furnish the varieties ordered, we shall substitute others which we deem equal or superior, unless instructed not to do so.

We Guarantee Safe Arrival, in good condition, of our trees and plants. Complaints. if any, must be made on receipt of goods; we will not hold to our guarantee if this condition is not strictly complied with. Should any mistakes or omission occur, we beg to be notified, and promise speedy and ample reparation.
\end{abstract}

True to Name-We warrant every tree and plant sent out by us to be true to name, and we hardly think any nursery in the world of equal size makes so few mistakes, but I have to employ many men. All are not careful or experienced, so, should any varieties prove to he different from what they are labeled, I will return the amount paid for them or furnish the trees, but am subject to no other claims for damages.

We Pay Express on Orders for $\$ 3$ or Over-In order that our customers may know exactly what their trees will cost, we prepay express to any point in the State on orders for not less than three dollars' worth of stock, and on orders for not less than so I will pay the express to any express office in the U.S.

Our Traveling Salesmen are hereby commended to the public. We endeavor, as far as possible, to secure the services of salesmen well known by the people to whom they sell, and who are competent to give the particular information required in the selection of an orchard for any location, and who being perfectly familiar with our varieties, can give any special in. formation that may be desired. They do not sell at fancy prices, but at the prices quoted in this Catalogue. Our object in employing salesmen is simply to place our stock before the public, and we pay them cheerfully. believing that those who buy from us once will continue to do so. While we commend our salesmen to the confidence and kindness of the public. we may be deceived by some, hence we are not responsible for their debts and for special con. tracts they may make.

My Shipping Facilities are unexcelled, over the H. \& T. C., the I. \& G. N. and the M. K. \& T. railroads, and the Wells-Furgo, Pacific and American Express companies.

Explicit Directions should be given for marking and shippıng orders. If express offlce is different from postoffice, this should be stated on the order sheet.

Terms Cash-Remittances should be made by postofflce or express orders, or by bank draft on Austin or New York. All accounts are due and payable at Austin. Those with whom we are not acquainted will please send cash with order or instruct us to ship C. O. D.

I accept checks in payment of bills.

If Anything Dies within one sear from time of delivery, I replace it at bale price, and if the bill amounts to three dollars I pay express to any express offlce in Texas.

Get Familiar with trees and plants by subscribing for and reading Texas Farm and Ranch, of Dallas, $\$ 1$ a year. I enjoy selling to well posted customers. Write the De La Mare Publishing Co., of 170 Fulton Steet, New York, and the MacMillan Co., 66 Fifth Ave., New York, for catalogue of books for Farmers' Fruit Growers, and Florists.

See inside back cover for Directions for Planting. 


\section{ORDER SHEET}

The Austin Nursery

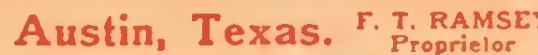

Date

My Name

P. 0 .

R. F. 0.

County of

State of

Express Olfice

If yos preler to noy whee received, eork $C, 0.0$. bere

\begin{tabular}{|c|c|c|}
\hline \multicolumn{3}{|c|}{ AMOUNT ENCLOSED } \\
\hline Cosh & 3 & P. 0. Order s \\
\hline Check & 3. & Express Order \\
\hline Exchange & . $s$ & Postağe Stamps S \\
\hline
\end{tabular}

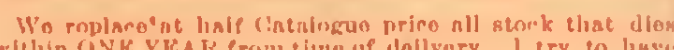

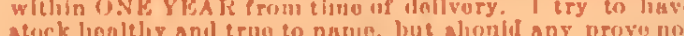
to lou. I will furnish it frun, or roturn aunount paid for Bainis, but am nubject to no othur d lamages. if gou aro net arejualnted witli varletles tlast aro best for your goctlng. nud will outling whint gou want. and

If I out of a virloty orilnredl, a nil you ollow mo to pnt in

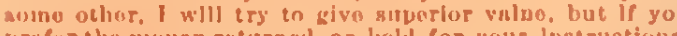

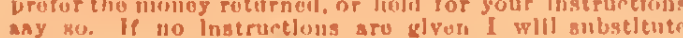

Miny I du nol Say YES or NOO

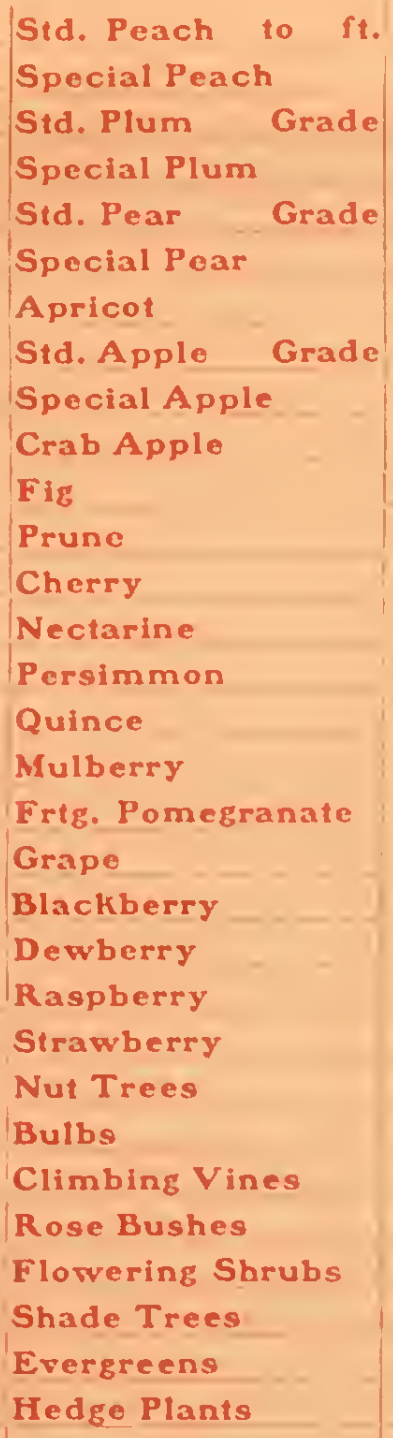

Amount ...
Alexander

Alenn

Anxibel

Arp Benuis

Anguats

Barrana

Kells Detn

Beatjunn

Burnap

l3oteram

Cabler' Ind

Carman

Carpentar

Champlon

Chilow

Chlneso Clg.

Columblana

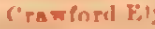

Crawencil leta.

Crosty

Deway

Eily. ("hlnn

Filhorta

Equilnox

riat. Donm

Hiverhearlng

Farnlly Fav

Fonter

(ine Camphellso

กิn Hinge.

Gov. Janham

Grmanatinen

Guinn

Honth

ITriliann

Honey

Impinrial

Iud/an ("Ig

Jacksnn

Jap Dwar?

Laily Palm

Lan

Lornn

Ioril Palm

Lnvoll

Ros

Matlo. Jity

Mayllnwor

Misa ylay

Mixnn Cle.

Nixnn Fren

Mulr

Nix

Oetolnerta

Ondordonk

Pallos

Phlllys

Piequate

Rameay lia. son

Rivera

Rogers

Ruplny

St. Jnhn

Salway

Slapgy

Snneal

Snow Cly.

Spmnes

Stinaon

Stump W.

Sugar

Sylphide

Taylor

Thompsn

Thurber

Triumph

Vletor

Wesrer

I shall be grateful if you u'ritc on other side the nrmes of a feu persons who muy need trees or plants, to whom I may send my ertiles.

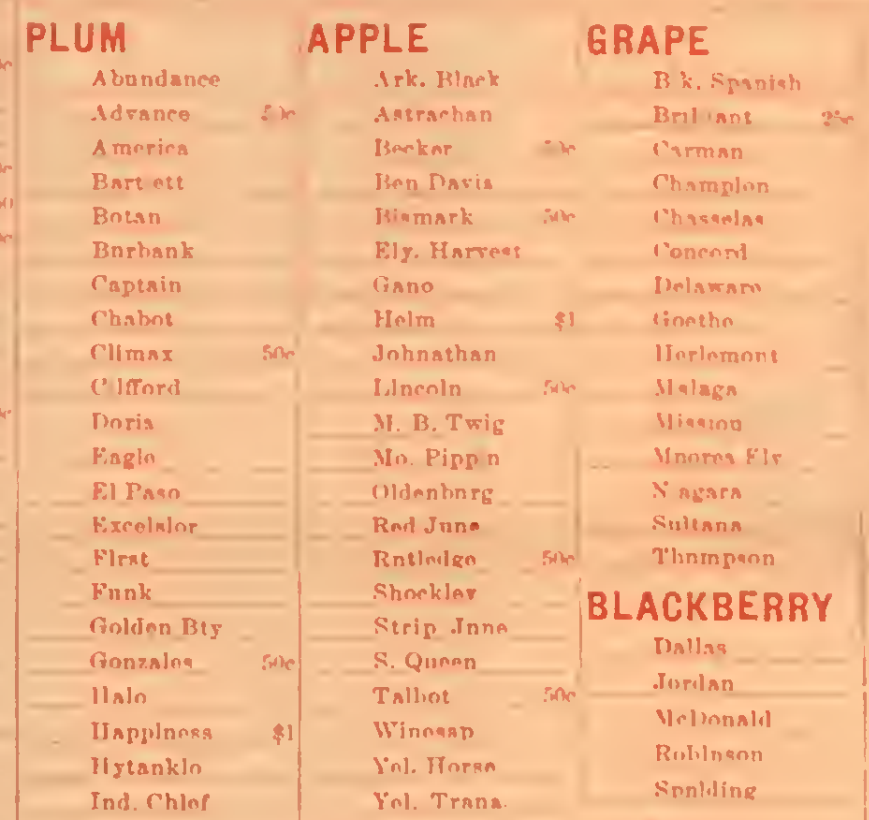

ROSES

Am. Rearity

Rnl, $\operatorname{li} a n !$

alies, $13 n$ '.

Ito a Imo

Iirsiln

Bridosiga

linrliank

('hip of wine

cinifyert

(th of linlil

Crim. Ramb

IJInemeto

king oft tha .

rat. Pradsel

kt]. 1) t.yen

F. F. Irlllaril

(i) .I aquominne

Ilalen livul|l

II alon lioula (') Is.

Kalanrina

Liaiarer na cilb.

la franete l'k

la k'ranen kid

l.a freranes Whil

LA Namid

lin Traen

Lilingte

Me Irthitr

Jecarinat

11.1m Bamant

11 I' Taupnnt

IInlmnann l'Ink

Yalumann Why,

3) Noll

II Nall

II. Nonl

"I Sall IRw

Ilome Plnk

IInae Whilten

31. W"aslugen

Mapasit

Matant Clh

Papa nentio

P Ninprou

P Xingron Mll.

$P$ of imarilen

Qunan. Selt

H V: Iman

li MI II un rintea

Safrano

Sinvan QInt

Snlesatara

Bnnuat

TIpllez.

Vleka r'ap.

W. A lRIah fin

White Raml.

Yel Ramnt,

FLG. SHRUBS

lily Jas e e

liteta $\ln x$. Sar

filly $\mathrm{Ra} / \mathrm{n}$

Lilly Yal hay

Trlenmn

Tnion Knse

CLB. VINES

Antlgonno

("amat'a Blues

rlematis Harl

MULBERRY

\section{Blenhelm}

Bods

rinstar

Ely Bnliten

Gnlden $\operatorname{Drm}$

Helungk' $r k$

Immpark

Rornl

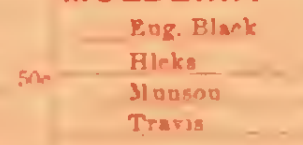

POMEGRAN'TE

Erartentiog $\frac{\text { Jemobson }}{\text { Span. Rubr. }}$
Althen Iikht

A Ithon l'lnk

A Jthona Purp.

Althea Rarl

Althes $T$ Alha

Althea

Alshar Whiten

('. Ja 1 .

C. Ja mlna

C. Jyrte T'k.

c. 31 rotio \&els

C 31 minta Whe.

Ciralterry

Elderherry

Snowtharty

rent. Plant
FLG. SHRUBS

10anis

can aluriom

lats phylum

1.llae Iurgile

l.llar Whe

Malvar acua

Mis Lunrel

Parona

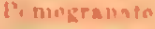

V" " easal

limel |lnol

Sintorl

Npanl hothe

spirms lllue

spiran lis] Whe

Epimasel Wht

Nedp Cystrums

Sumarli

Whor lollar ple

Wilu lines ple

WIw Whe Fis

SHADES

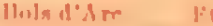

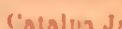

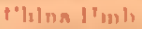

(')। Ins WII.।

Cotton wond

F.Im

llanklearry

Varntah

bivn Onk

l.mpuat [H]k

Mulliarry stied

181 a lan $\mathrm{N}$ |1

lonalomenla

Buplar Cara

lupiar Let in

luplars lonaf

Ayennu in Am

Syennurorat)re

Tnmarix

WII Wigy

EVERGREENS

A reor $V+l^{\prime}$

Arliaip $V$ matil

Arma. V PV m.

irl, V IR al

It. $x$ Tre

tomelar lle

inderthed

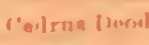

"ygre: |11,

t'ypre a'Pyrn

Knony" n⿳

l.19m: trum

Maontuln fI

I'rivit A mritit

HEDGE PLNTS.

Alor Vlian

litronymana

Mork (Jranga

liumegranata

Prele et in e.

Rosen romar'kmen

Romen Hernany

GRASSES

Aruma? 1

Inmon

Mork Pampas

Pampas

Tol ra

PALMS 


\section{REMARKS:}



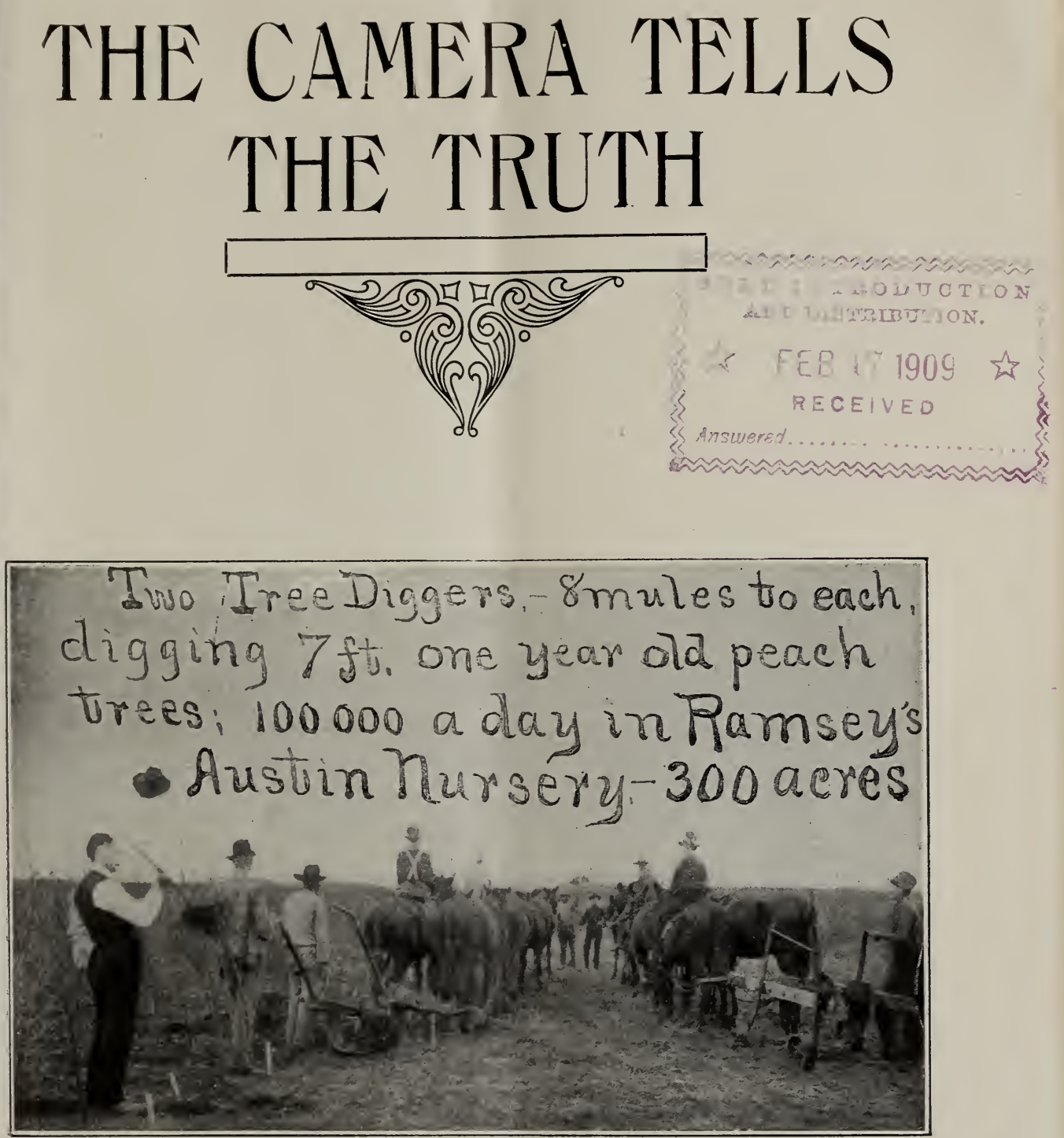

SOME VIEWS

OF THE AUSTIN NURSERY AND ITS PRODUCTS 


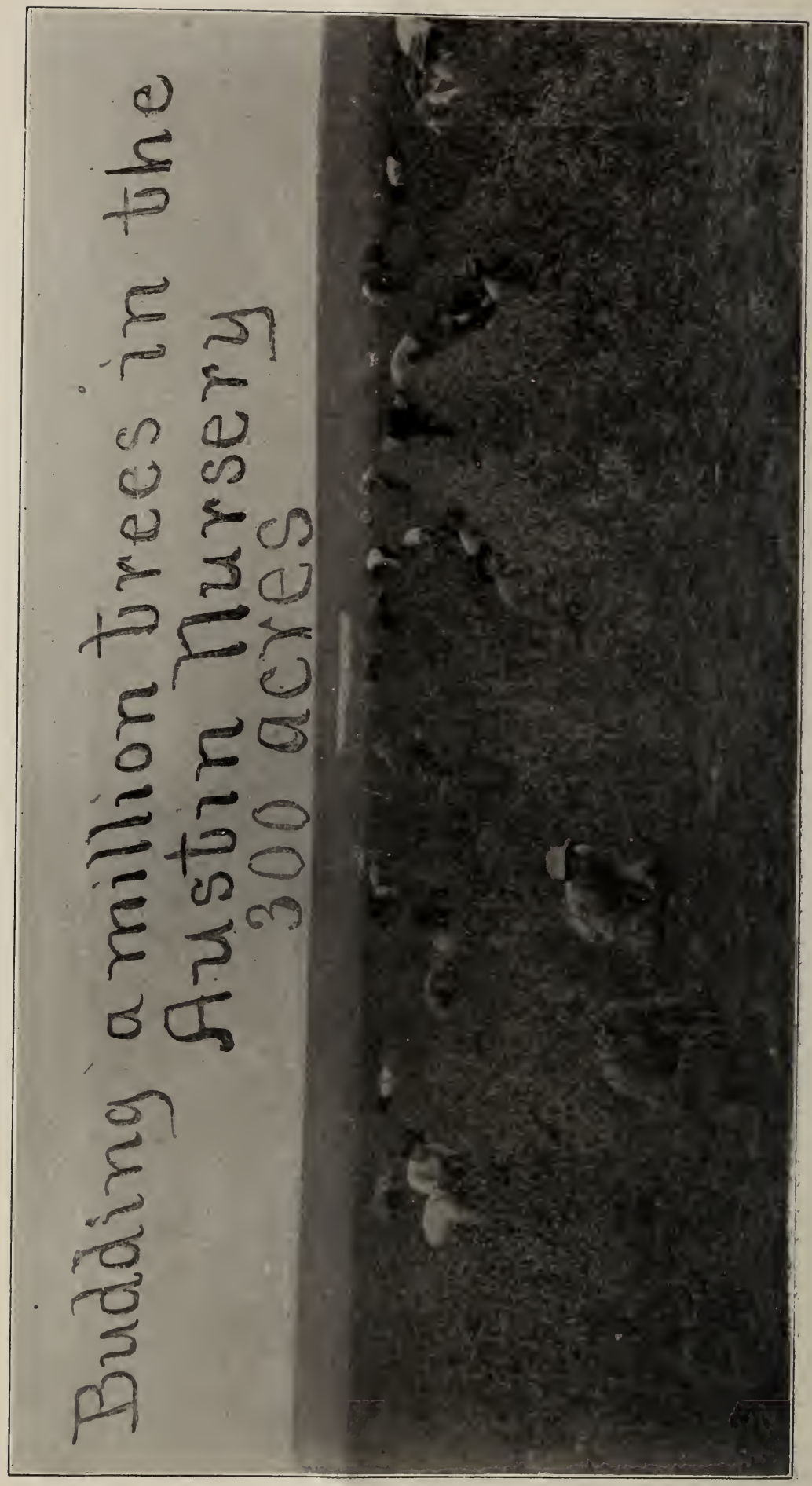




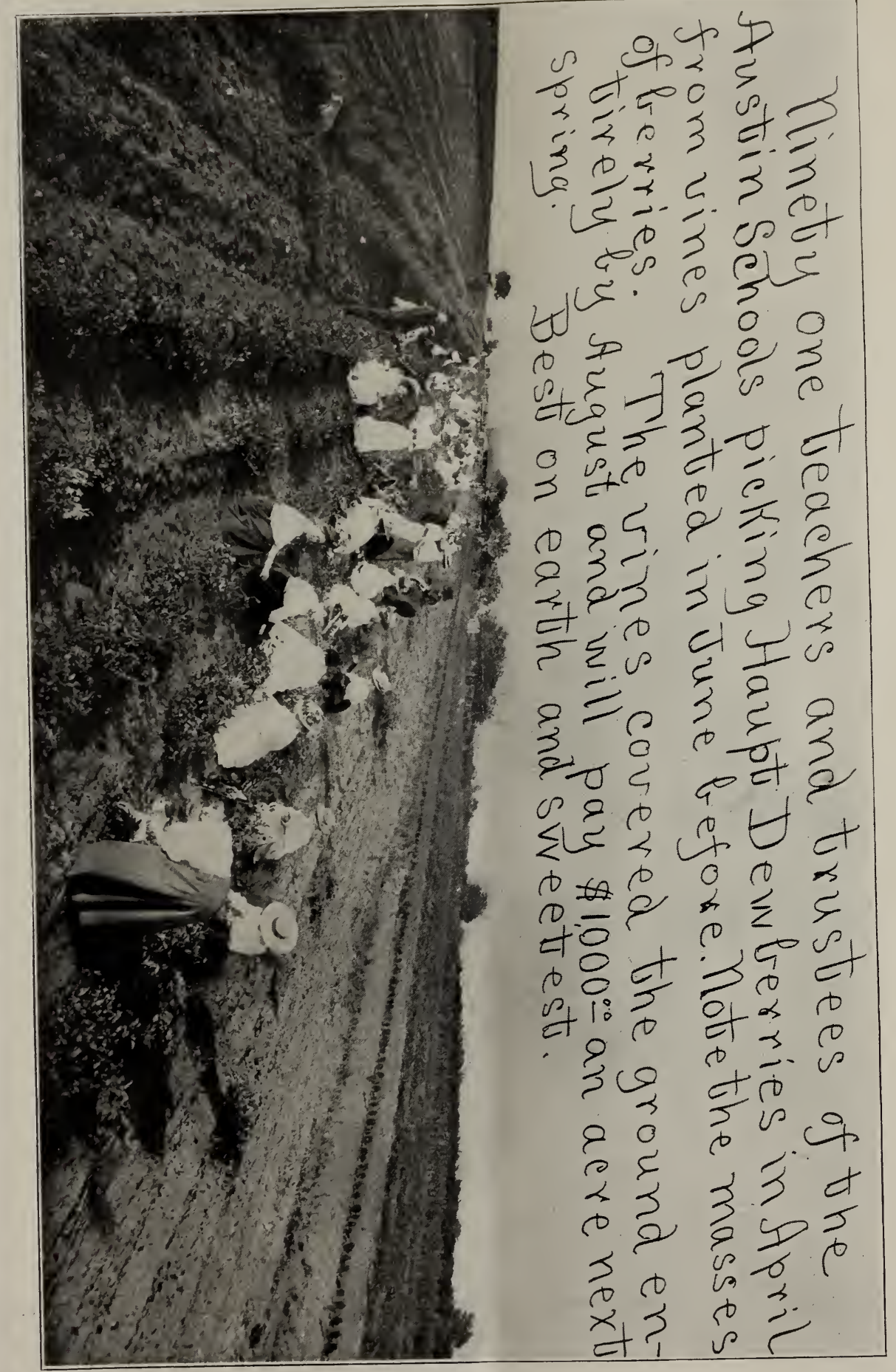




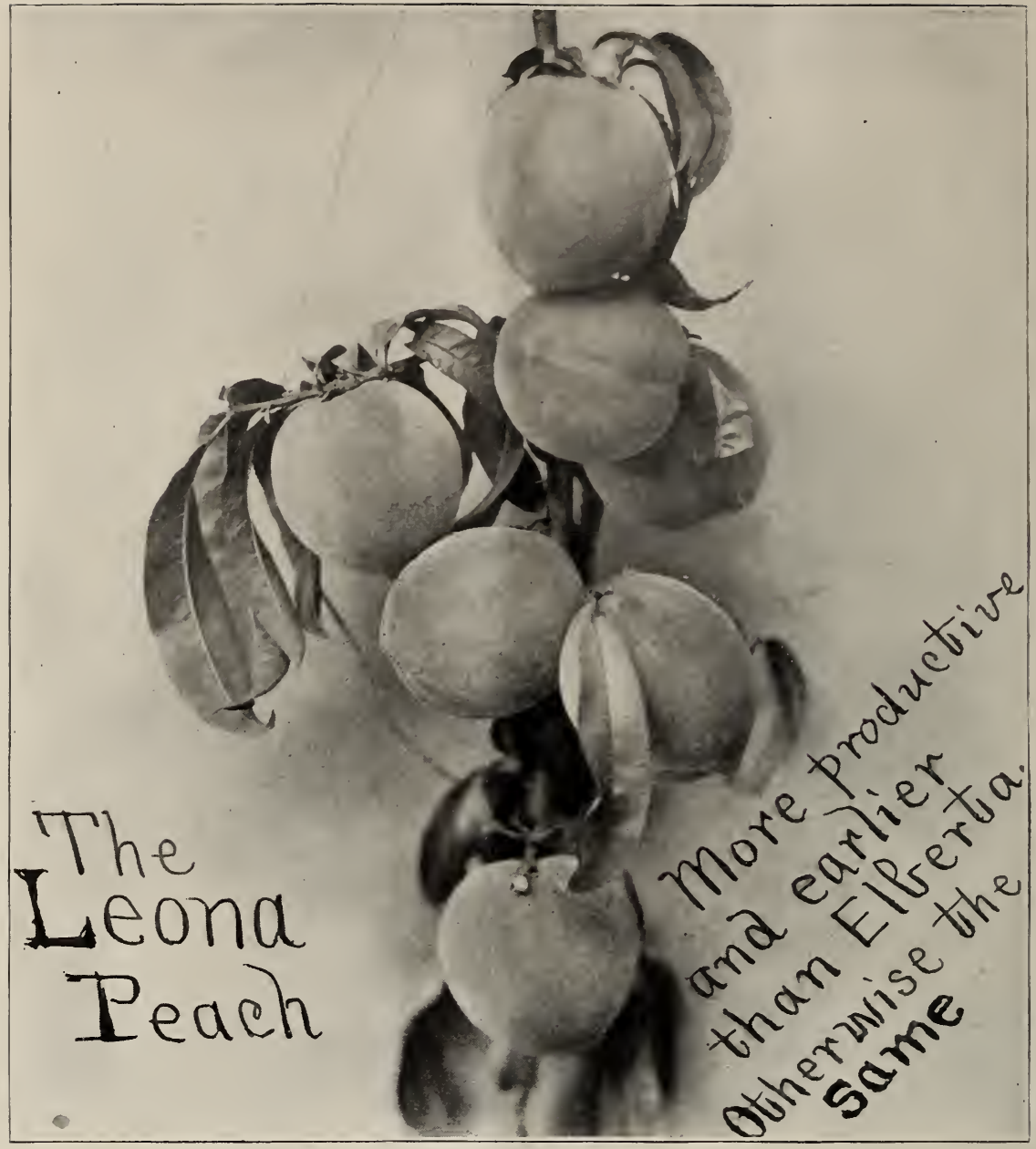

Anyel lilies. (Crinum fimbriatulum) Blooms all summer. Delighliful fragrance. They will bloom for a lifetime without being moved

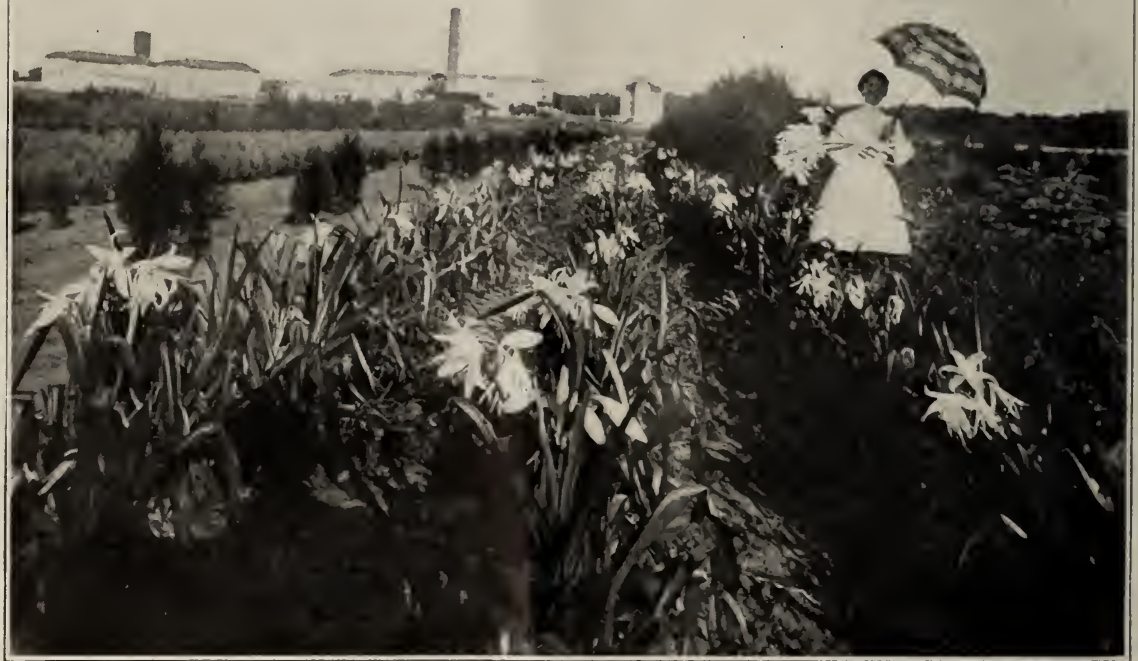




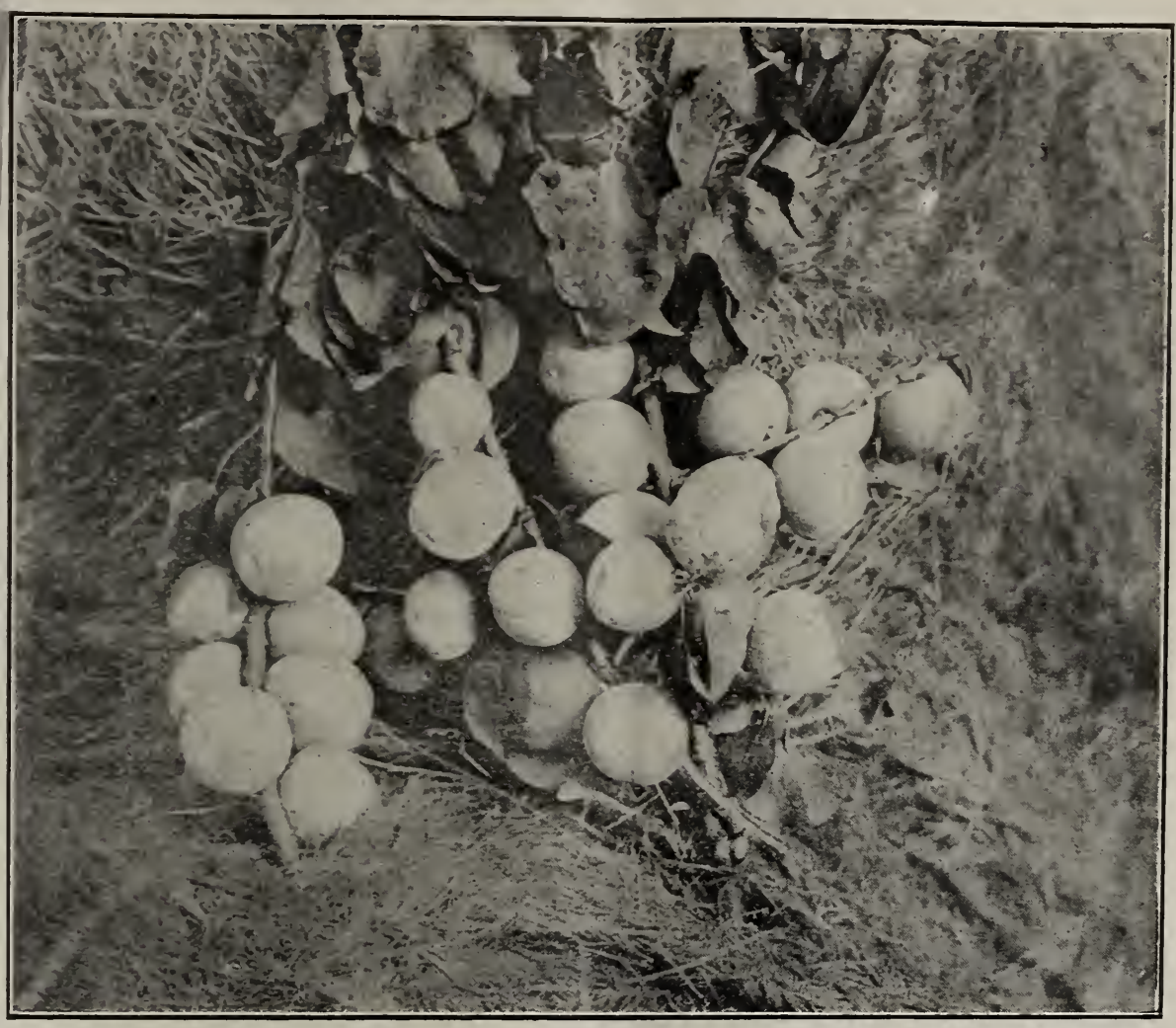

Cluster Apricots grown at Lampasas on three year old tree sold by the Austin Nursery.

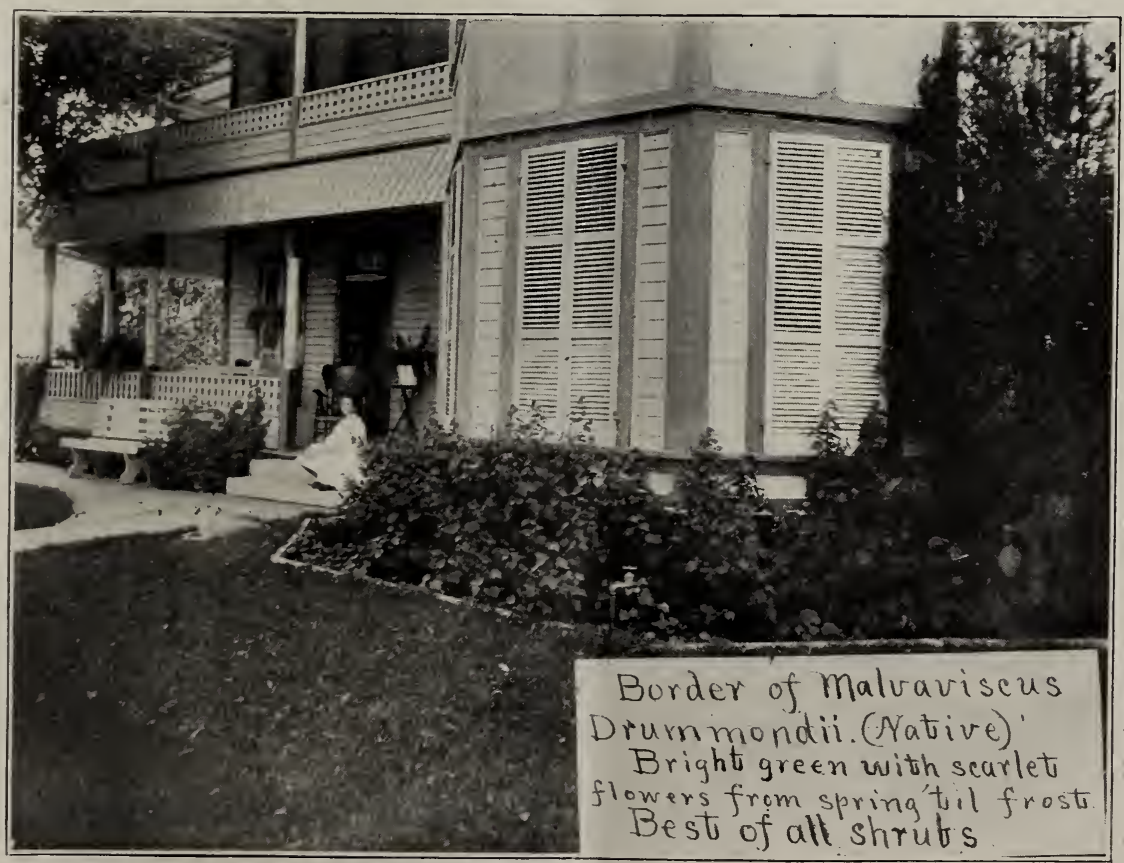



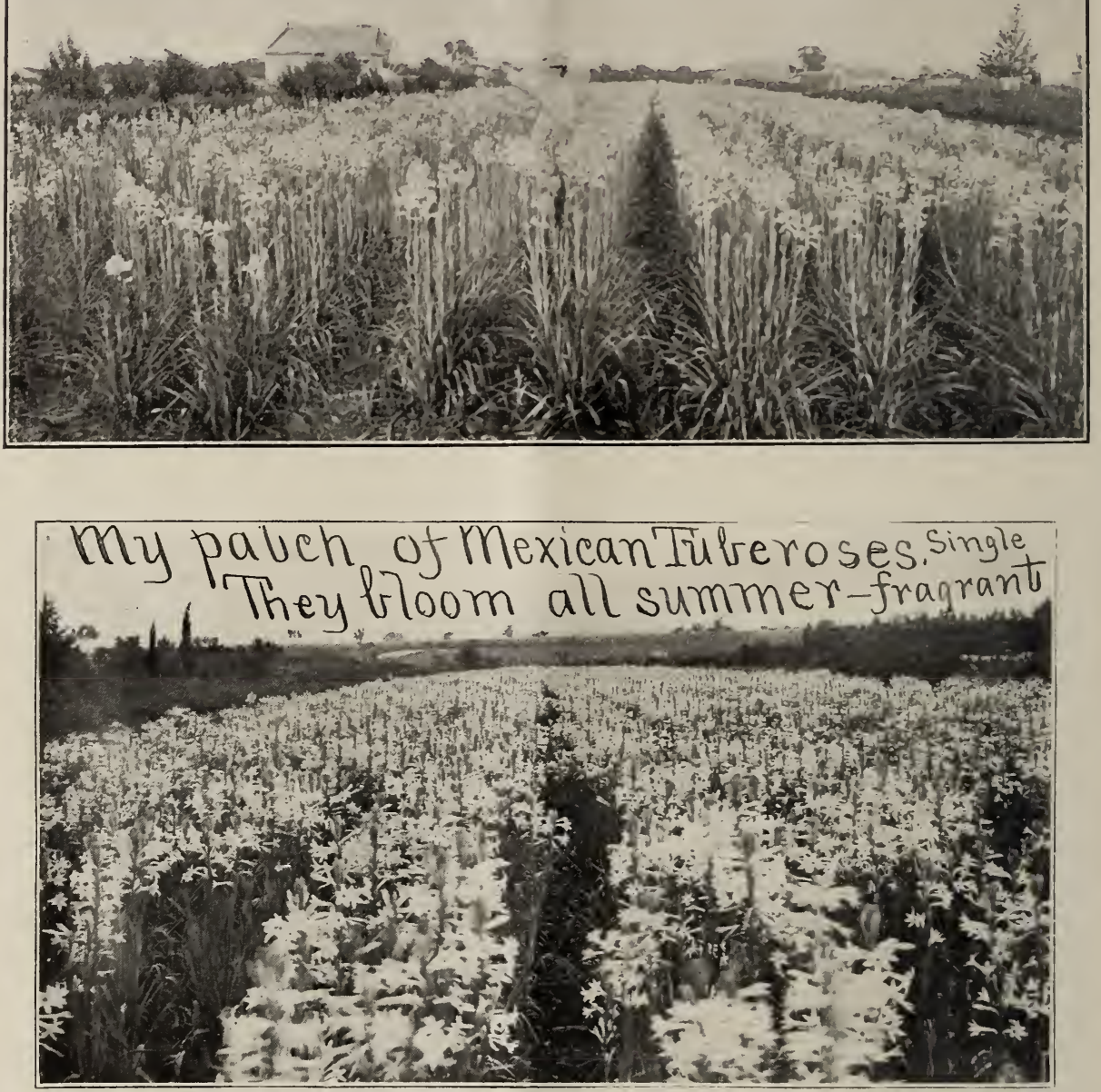

Beautiful Rosedale Arbor Vitae. They orig inated in Texas. Cape Jasmines flooming beyond Atien-acre rose patich in the distance.

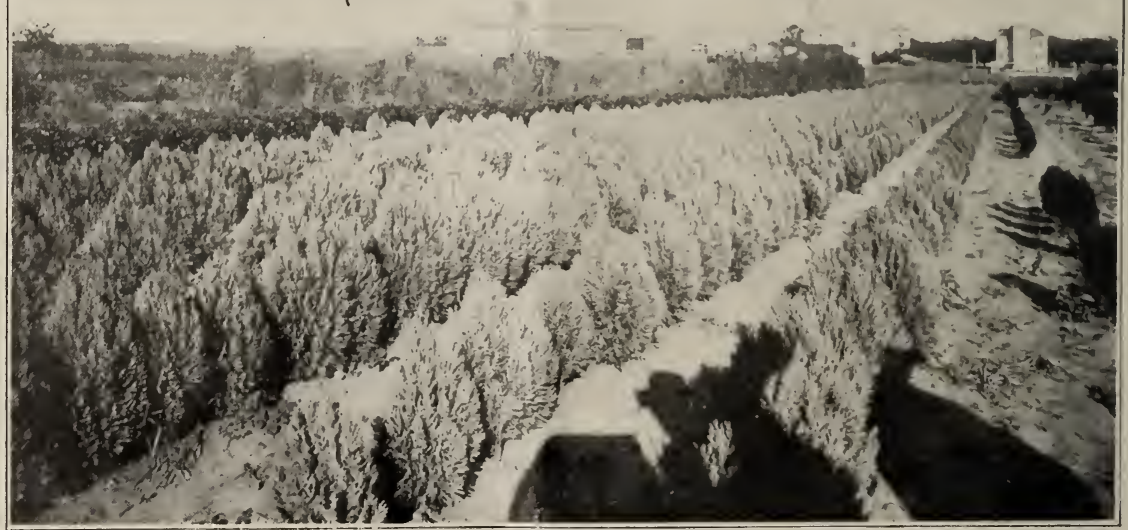




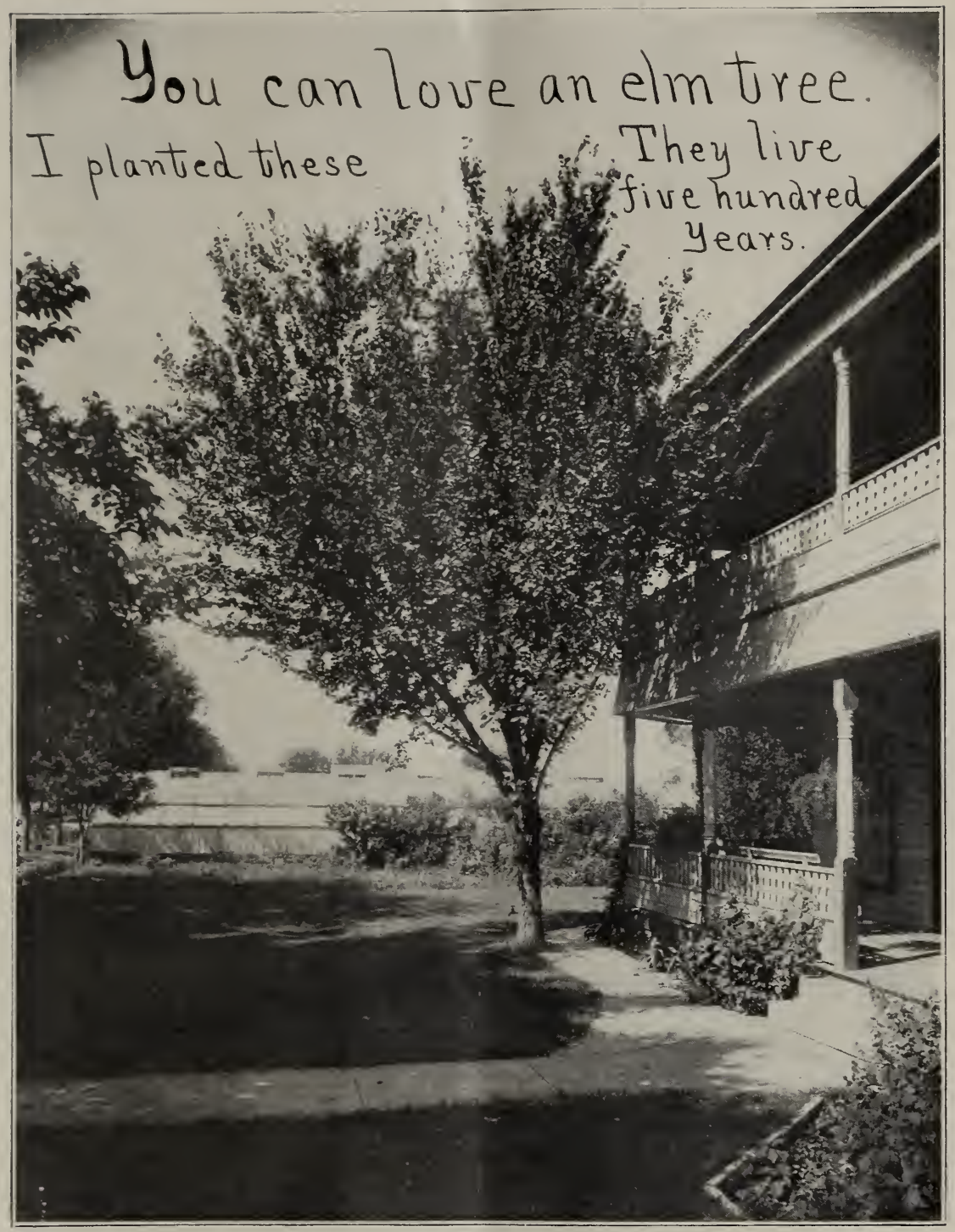

I have thousands of fine shades of all kinds: Elm, Hackberry, Sycamore. Cottonwood. Black Locust, Box Elder. Catalpa, T'mbrella China, Nonbearing Mulberry, Carolina Poplar, Lombardy Poplar, Live Oak, Ligustrum.

Every country home should have a grove of Chinese Arbor Vitue around barn and on north of residence

My stock of Urnamentals has been greatly increased. 


\section{FRUIT DEPARTMENT.}

\section{PEACHES.}

Plant from 16 to 20 feet each way. Cut tops back to 18 to 24 inches as soon as planted. Cultivate often. For number on an acre, see page 3 cover.

There is no fruit that is more universally successul in Texas than peaches, but one must observe that different strains must be planted in the different sections. It would be useless to plant varieties of the South Chinese strain toward the northern part of the State, and no less wrong to plant varieties of the pure Persian strain on the coast. Over the greater part of the State the best strains are the Nortl China, represented by Mamie Ross and Family Favorite, and crosses between it and the Persian race, represented by liberta and Governor Lanham.

I believe Texas leads the rest of the world in the number of really valuable new peaches and other fruits it produces. Many new varieties are sent me each season. I have fruited hundreds of varieties in my own test orchards, and feel justified in saying that the collections I offer for the different sections of the State are not surpassed.

I give my list alplabetically, and the date of ripening is about the average at Austin.

$$
\text { Prices, express paid: }\left\{\begin{array}{l}
2 \text { to } 3 \text { feet, } 10 \text { cents each, } \$ 8 \text { per } 100 . \\
3 \text { to } 4 \text { feet, } 15 \text { cents each, } 12 \text { per } 100 . \\
4 \text { to } 6 \text { feet, lieary, 25c, } 18 \text { per } 100 . \\
5 \text { to } 7 \text { feet, extri fine, 35c, } 25 \text { per } 100 .
\end{array}\right.
$$

ALEXANDER. May 20th. The old, reliable, early peach; sure bearer. Arkansas Traveler, Jessie Kerr and some others if not identical are so much like Alexander that I do not grow them separately.

ARP BEAUTY. A Smith county seedling that is atracting great attention. It resembles Elberta, but ripens entirely before it. East Texas growers are planting thousands of it. Price, 50 cents.

ALION. Proving to be of extra value on the plains and in the $T$. P. territory. July.

AUGUSTA. A seedling in my test orchard. Large yellow freestone, finest quality. Seems to be a cross between Elberta and a common vellow seedling. Extra sure bearer. A month later than Elberta. Best August peach I erer saw. Price, 50 cents.

BARNES. A pale wine-colored Indian cling of superb quality that ripens in September; flesh yellow.

BELL'S OC'TOBER. Large, fine, yellow freestone, red cheek, that originated in Denton county. October list.

BESTJUNE. A reedling in Fayette county that might be called an improved Mamie Ross. Enormously productive year after year. A prize for South Texas. Price, 50 cents.

BUTTRAM. A large, yellow, fine-flavored cling that originated from seed in the old Buttram orchard in Deaf Smith county. It rifens there September 15th. The elevation is 3600 feet, and the common varieties of peaches do not bear regularly. This peach and Thompson and Paladuro were produced by nature for the plains. They bear where others fail. Any orchard in the whole Panhandle will not be complete without these peaches. Price, 50 cents.

BURNAP. Large white eling resembling Chinese Cling but the most prolific and precocious of all large peaches. A seedling in the vard of S. L. Burnap, of Austin. Two-year-obl budled trees were wonders with their crops of fruit. July 10. Price, jo (ents.

CABLER. A light-colored Indian cling, ripening early in July: perhaps the earliest pure Indian Cling. Introdnced many rears ago by Mr. Onderdonk in Victoria county. It suceeeds far South.

CARMAN. A large, white freestone with red eheek that originated in Limestone county; fine flivor. Ripens July 5th.

CARPENTER. White ching; ripe July Sth. This peach has literally borne full for eight succesive rears. Possibly it has borne more bushels thin any variety in my orchard. It is one of the very best for South Texas, and as far north as Missouri those who have it want more.

CHAMPION. A superb white freestone of very highest quality; ripe July 10th. One year at our State Horticultural meeting it won the gold medal for the best plate of peaches in the State. 
CHILOW. A pure rellow ding: ripen. Iuly loth. A seedling of Chinese Cling, but, like it, parent, has borne every year for nine years. Very firm, and no peach will keep longer or ship further. Few peaches equal it in quality, and none surpass it. I doubt if it ever fails to bear a good crop, but it never bears too many. One critical fruit grower one rear said he would take two liundred trees if he could get one hundred and seventy-five of them of Chilow. The most delicious canned goods of any kind from any State in Austin are a few cases of Chilow that were sliced thin before canning. With some new varieties. praises are loudest the first year; not so with Chilow. I have nerer grown enough of the trees. so will continue to sell it at 50 cents each; 10 trees $\$ t$.

CHINESE ClING. July l0th. Perhaps the very largest white cling that grows. Juicy, but not prolific.

COLCMBIANA. I freestone Indian that originated near Austin. Large. Color less vellow and more wine-color than Columbia, and so superior on every point that I do not grow any more Columbia. August. Price, 50 cents.

CRAITFORD'S EARLY. Large, yellow-fleshed, highly colored. July 5th.

CRATFORD'S LATE. Resembles Crawford's Early, but larger. July 20 th.

CROSBY. Very productive, medium size, round, yellow flesh. In great demand in West Texas. This is the peach often called frost-prove. July.

DEWEY. Said to be the earliest pure yellow freestone. June.

EARLY CHINA. Same as Rogers, which see. I keep both names because thousands are ordered under this name.

ELBERTA. Very large, yellow-fleshed, red-cheeked freestone. Ripens first half of July.

ESTHER DOOM. Originated from secd in the yard of Judge Doom, of Austin. One of the finest and most productive large, yellow, red-cheeked clings I have ever seen. July 25th.

EQUINOX. A very large vellow freestone, ripening September 22 d.

ETERBEARING. An Indian peach that is several weeks in ripening, commencing in July.

FAMILY FAVORITE. A white, red-cheeked freestone that practically bears full every year. Enormously productive. It is needed in every orchard. Julv 5th.

FOSTER. July 4th. Resembles Crawford's Early, but more productive in this latitude.

GOTERNOR CA.IPBELL. Cling. Large white productive. The old seedling tree in Austiul has hardly missed a crop for twenty-six years. July 20th. Price, 50 cents.

GOTERNOR HOGG. Large, white, tender cling, pink cheek; highest quality. July Sth.

GOTERTOR LANHAII. This is one of the most beautiful and one of the very largest peaches I have erer seen. The trees bear full of extra large peaches when only two years old. They are as large as the very largest Elberta, and the yellow and red is even brigliter than the shading on the Elberta. It ripens with Elberta, but is a cling, and the yellow flesh is very firm and will ship to any market. It originated from seed right here in Austin. I have never taken greater pleasure in introducing any new fruit. Price, \$1 each.

GREENSBORO. An oblong white peach that I believe is the most prolific of all the extra early peaches. Large size for an early peach. It commences to ripen the last days of May.

GLINY. A new seedling in Cherokee county that has been planted extensively by Mr. Guinn for several years. Large size. It becomes a very bright red color long before it is ripe, putting it in condition for shipping before it is soft. During a dry spell a couple of my budders went up and budded for Mr. Guinn. They put in over 50,000 buds of Guinn and not a bud of anything else. -The trees were already sold at double the price prevailing for other sorts. It ripens between Alexander and Elberta. Price, 50 cents.

HEATH. A good, old, standard white cling. August and September.

HOBSON, An improved Mamie Ross ripens earlier. June. Price, 50 cents.

HONEY. A mcdium sized white peach specially suited to the extreme southern part of the peach belt. The sweetest that grows. June.

IIIPERIAL. Taluable for the extreme South. Jume.

INDIAN CLING. For twenty-five or thirty years no peach grower has been able to grow the old-fashioned, real red-fleshed Indian cling, as large as it used to grow. With much pride and pleasure I announce that a Texas seedling I have secured in all points equals the best Indian cling of forty years ago. August.

JACKSON. A large white cling; a duplicate of the chinese in size and appearance, but bears abundantly. July 10 th. 
JAPAN DIVARF. Dwarfish, bushy tree. Generally half the flesh is red; sure bearer; does well all over Texas, and is perhaps the best extra early peach for the section between Austin and the Gulf. Ripens latter part of May.

LADY PALMERSTON. Large, rich yellow flesh. Scptember 1st.

LEE. Large, cream-colored cling; sure bearer. Ripe July 10th.

ILONA. Almost exactly like a bright Elbercta but ripens a week earlier and very much more productive. Two-year trees bear about as many peaches as four-year libertas. Price, jo (ents.

LORD PALMERSTON. Large white cling that ripens the last of August. Sure bearer.

LOVELL. A great farorite in California.

MAMIE ROSS. Large white red cheek. Between a cling and a freestone; wonderfully prolific and regular in its bearing. Ripens last of June.

MATHEW'S BEAUTY. A yellow freestone from Georgia that ripens later than Elberta.

MAYFLOWER. A yellow May peach of $\mathrm{N}$. C. origin. Attracting attention. Price, 50 cents.

MISS MAY. Medium to large white freestone that ripens in October. Very sure bearer.

MIXON CLING. Old reliable, large, firm, blush-white cling. July 20 th.

MIXON FREE. Luscious, white, with ${ }^{-}$blush. July 20 th.

MOUNTAIN ROSE. Prolific, bright-colored frecstone. Ripens last of June.

MUIR. Favorite for diying in California.

NIX. A large white cling that ripens in October and November.

OCTOBERTA. A yellow freestone, resembling Elberta, ripening in September and October. Price, 50 cents.

ONDERDONK. Yellow freestone. One of the reliable peaches for the extreme South. July.

PALLAS. Medium white freestone; deliciously sweet, and bears every year.

It is successful far to the South and Southwest. June 30th.

PHILLIPS. A July cling. A great favorite in California.

PICQUETT. A productive, yellow-fleshed freestone. Ripens here in August, but in North Texas in September.

RAMSEY'S LATE. A white cling resembling Heath that originated with Mr. Ramsey, near Bowie. It is my rery best September peach for three years. Productive, good and bright as a June peach. Price, 50 cents.

RIVERS. White, red-cheeked, tender freestone. Bears very young, and rarely misses a full crop. June 20th.

ROGERS. Very much like Mamie Ross, but of better quality and positively a surer bearer, and its successful range extends far down on the coast. June.

RUPLEY. A firm, round, medium-sized yellow cling of Mr. Onderdonk's introduction. Its best range is towards the coast. June.

ST. JOHN. Bright colored, medium-sized freestone. June.

SALWAY. An old standard yellow-fleshed freestone. Ripens here in August and in North Texas in September.

SLAPPY. A yellow-fleshed freestone, ripening ahead of Elberta. Some carload shipments from Georgia to the Northern markets brought extra fine returns. It is doing well in the extreme South.

SNEED. A white peach that was the first to ripen ahead of Alexander. Not very prolific, but bears some every year. May 20 th.

SNOW CLING. Large, white September cling. Nothing better for canning. preserving or for market. Mr. Fred Heep, living twelve miles soutl of Austin, for many years has found this his most profitable among many fine peaclies.

SUGAR. An improved Pallas. Most productive peach $\dot{I}$ ever saw. Very sweet. July.

SPENCE. An Austin seedling in general appcarance like Mamie Ross, but slightly larger, and of superlative flavor; flesh inclined to be mealy. Regular, uniform bearer. Last of June.

STINSON. Yellow-fleshed, red-chceked, October cling; a regular bearer, and one of the very best all around late peaches.

STUMP THE WORLD. Old standard whitc freestone; reliable bearer. July 15th.

SYLPHIDE. Resembles Lee, but three weeks later and a wonderfully sure bearer; rarely fails. It is needed in very orchard, as it comes in after the rush of July peaches. Cling.

TAYLOR. Freestone and like the biggest brightent Elberta, rather more yellow; a few days later than Elbcrta. Productire. A marvelous peach. Price. 50 cents. 
THOMPSON. A seedling in the orchard of Mr. J. D. Thompson in Deat Smith county. Another peach for the plains. If you live on the prairie, plant it. Large, yellow, fine flavor. Cling. Price, 50 cents.

THURBER. Medium to large, white, red cheek. While this peach is fairly good on all points, it excels on none, except in its habit of bearing a full crop almost every year. Very hardy, robust tree. July 5 th.

TRIUMPH. Medium size, yellow, free, red cheek. It bears too full is all one can say against it. One of the surest croppers. June.

VIC'TOR. A new seedling of Sneed and is a few days earlier. I consider it the very earliest of all peaches, and is a better bearer than some other May peaches; medium size, white with blush. May 1Sth.

TTEATER. Originated from seed in the yard of Mr. D. W. Weaver, of Austin. I grew ten thousand trees of it for Mr. Weaver before I secured the right to grow and sell the variety. It has now borne several years in my orchard. A yellow cling overspread with red, often measuring nine and ten inches; flesh very yellow and very firm; of very best quality. During the nine years I have know it, it has not failed to bear; always ripe the lst day of September. No peach brings a higher price in market. The trees show some Spanish blood (old Texas seedling type). I lieartily commend it to my customers. A few years ago I sent some trees to Mr. Falkner, of IVaco; as a result he has ordered a thousand trees each year for three years. He told me no peach in his large orchard paid as much per tree as the Weaver. Nearly every man in Austin when he goes to his place of business during the first half of September carries some handsome Weaver peaches to show his friends how fine they are. The demand increases so much each year that I have never been able to fully satisfy it, so I shall continue to sell it at 50 cents.

WHITE INDIAN. A superb white cling showing faintly the wine-colored veins of an Indian peach. A most regular bearer; quality enticing. It is good for all purposes. It is nerer surpassed by any peach. Ripens in September. \$1.

\section{A List of Good Peaches for South and Southwest Texas:}

Bestjune, Cabler, Carpenter, Early, China, Honey, Imperial, Japan, Lee, Mamie Ross, Onderdonk, Pallas, Rupley, Sugar, Slappy, Thurber, White Indian.

\section{A List of Good Peaches for the Plains:}

Buttram, Champion, Crosby, Diamond, Greensboro, Heath, Lady Palmerston, Lee, Lord Palmerston, Mamie Ross, Salway Snow Cling, Thompson, ITeaver.

\section{A List of Good Peaches for the Panhandle Below the Foot of the Plains and for the North-Central Prairies:}

Alexander, Buttram, Carpenter, Champion, Elberta, Family Favorite, Governor Lanham, Lee, Mamie Ross, Mixon Cling, Rivers, Roger's, Spence, Stinson, sylphide, Thompson. Thurber, Leona, Ramser's Late.

SEEDLITG PEACHES. Two years old, from good mixed seed, 15 cents; $\$ 10$ per 100. Small one year common seedlings for grafting, \$2 per 100; $\$ 12$ per 1000.

\section{Facts About Peaches.}

The peach is strictly a deciduous tree. The leading varieties of large peaches do not produce good crops after a warm winter.

If a person stays awake all night, he has not much energy in the morning. If a peach tree stays awake all of a warm winter, it has not much energy in the spring, and a poor crop is the result. My list contains sure bearers for Central and Southern Texas. They are natives and of the Southern Spanisl strain and have been selected on the records they have made for bearing regularly. 


\section{Plums.}

\section{CLASSIFICATION OF PLUMS.}

I do not want to increase the confusion, and without considering what might bc the best classification to guidc experts, I believe the following to be the best to guide retail buyers, for whom I am writing this catalogue:

I. CHICKASAW (C.). Thorny zigzag growth. Blooms rather early. Leaves narrow and trough-shaped. Suckers freely from the roots if not grafted.

II. CHICKASAW OF THE WILD GOOSE TYPE (Marked W. G.). Smoother growtl. Blooms later as a class. Larger leares. Suckers less. Stronger growth. It is hard to tell to which of the above groups belong some varieties.

III. GOLDEN BEAUTY (G. B.). Bark of limbs rather yellow or light color. Leaves very large. Blooms latest. Ripens late.

IV. AMERICANA (A.). Large, coarse growtl. Blooms late. Fine quality. But few varieties are valuable this far south.

V. HYBRIDS, or crosses between Japan and one of the above groups.

VI. JAPAN (J.). Well known, smooth limbs, large leaves.

VII. AUSTRALIS (AU.). The large wild plum plentiful over Tcxas. Fruit generally ripens late. Formerly classed as Americana. Trees live to be very old and sometimes measure a foot in diameter.

The above varieties are believed to contain all varieties that can be generally recommended. There are various other types not generally valuable in Texas.

Of all the fruits that grow in this country, I consider plums the most successful. A few years ago all the varieties that were worthy of planting ripened within a period of six weeks. Now the season is extended to five months-from May lst to October lst.

Then the only good variety was the Wild Goose. Now there are dozens that are of more value.

I advise my customers not to plant Japan plums exclusively, for I offer a number of varieties of native plums that surpass, as a rule, tiie Japan in the number of bushels a tree will produce and in the quality of the fruit.

Over a large portion of the State in every family orchard I would recommend that of every hundred trees planted, not less than thirty-five of them sliould be plum trees, and on some locations more.

I have a few varieties of plums that under ordinary treatment have produced good crops of fruit about fourteen years out of fifteen, and nearly all the varieties I name are making the same record under my treatment of winter cultivation.

Frequent cultivation all the year sounds expensive. I tried various designs of wide-cut plows, and have settled on the plow illustrated on another page. I recommend one that cuts four feet until the land has been kept clean a year or more, but I use one that cuts five feet. Two rounds between my orchard rows annihilate every weed, and gives that complete, level and shallow cultivation so long recommended by intelligent orchardists.

Plant from 16 to 20 feet apart. Plums seem more fruitful when there are many different varieties in an orchard, as they pollenize each other more perfectly. All varieties arc budded or grafted on peach seedlings. I also grow some leading varieties on Marianna. See list on page 9 .

\section{PRICES.}

Except where noted: Best grade, usually one-year-old, 4 to 6 fect, 25 cents each; $\$ 20$ per 100. Lighter grade, 15 cents each; $\$ 12$ per 100. (Note: The best one-year trees of Golden Beauty and scveral Chickasaw varieties are often less than four feet high.

ABUNDANCE (J.). Strong, upright growing tree; fruit large, round, red, deliciously sweet. I am unable to distinguish any difference between this and Botan. June 10th to 15tl.

ADVANCE (J. X. W. G.). A very large, firm bright red. Extra early May. Tree wonderfully robust on all kinds of land. A Texas seedling that promises to eclipse early plums.

AMERICA (C. X. J.). A cross between Botan and Robinson; enormously productive; medium to large, first yellow and then red. July lst.

BARTLETT (J.). A cross betivecn Simoni and Delawarc. Trce beautiful upright grower; fruit round, red, with yellow spots; flesh salmon colored; quality very finc. It really tastes like a Bartlett pear. June and July. 
BOTAN (J.). See description of Abundance. A great favorite. June.

BURBANK (J.). One of the most popular and valuable plums. Tree spreading; awkward grower; fruit firm; bears very young, and rarely fails. June and July.

CAPTAIN (G. B.). Firm, yellow, slightly larger than Golden Beauty, and of better flavor. (It was formerly called Columbia.) August.

CHABOT (J.). Large, firm, yellowish flesh. One of the best. July.

CLIMAX (.J.). This is one of Mr. Burbank's farorite introductions. Bears young; fruit of exquisite flavor. Ripens in June. A cross of Simoni and Botan. Very large, measuring $6 \frac{1}{2}$ to $7 \frac{1}{2}$ inches. So fragrant a whole house is perfumed with a single fruit. Mr. Burbank continues: "Productive as the Burbank, four or five times as large, two or three weeks earlier, and very much more richly colored. The most wonderful plum ever grown, and one which will change the whole business of early fruit shipping." Price, 50 cents.

CLIFFORD (W. G.). Large, red, meaty; fine American flavor. June.

DORIS (J. X.). This fine plum has now borne several years, and I like it better each year. When Mr. Burbank introduced Doris and Shiro plums, he sold graftingwood at a lower price than was asked for some other varieties. They both contain Myrobolan blood, which makes the trees outgrow anything in nursery or orclard. Doris was loaded down last year and began ripening the first lays of Jume. In shape and size it is like a large Botan, but is of darker color. It is decidedly earlier than Botan and every plum from the first ripe to the last is superlatively sweet. The skin is very thin but strong as linen paper. It colors before it is ripe. I kept some nine days and they were at their best for eating. If there are two plums in the world entirely free from rot they are Doris and Shiro. I sold Doris first at 25 cents, but as the demand for it could not be half supplied, I shall not sell a tree this year for less than 50 cents each.

EAGLE (W. G.). Has made a fine record in North Texas. Medium size, yellow and red; sure bearer; called the everbearing plum, but it is not so good on this point in the south half of the State as El Paso. July.

EL PASO (C.). Red, medium size; some round, some slightly oblong; sweet when thorcughly ripe. In my orchard I have had two or three varieties bear more bushels in one crop, but in a series of eight or ten years I doubt if any variety has equaled El Paso. It has had enormous crops every year. Specially suited to the south half of the State. When overloaded, it ripens slowly. I have picked ripe plums off of a tree for three months, commencing the last of June.

EXCELSIOR (J. X. C.). Purplish red, large fruit; flesh, light straw color. Possibly this plum succeeds further south than any I sell. It is valuable here, and can be recommended for planting on the extreme coast.

FIRST (J. X.). Introduced by Mr. Burbank in 1901. A combination cross of several strains of plums. He says it blooms late and is the handsomest and largest of all very early plums.

FUNK. Instroduced by $\mathrm{Mr}$. Munson as the best early plum. Appears to be a cross between the Americana or Golden Beauty family and a Chickasaw. It is lighly praised by the introducer. I offer it at his price, $\$ 1$.

GOLDEN BEAUTY (G. B.). Introduced by Mr. Onderdonk many years ago. While the Wayland was perhaps the first of the type to become popular in the Central-Western States, Golden Beauty hold this honor in Texas. Fruit mediumsized, yellow, not sweet until fully ripe; leaves very large; resists drouth. August and September.

GONZALES (J. X. W. G.). It is several years since I introduced the Gonzales, and, in spite of the fact that I sell it at a higher price than the general r!n of varieties, I have never been able to grow enough to supply the demand. For quick and certain returns it has made a reputation over many States. Color a brilliant red. It combines the pleasant sweetness and juiciness of a real good Wild Goose with firmness and flavor of a Japanese plum, and yet has a distinct flavor which those who have tasted it say reminds them of nutmeg and vanilla. It is unsurpassed and hard to describe. I kept some fruit in good condition for a week after it was ripe in a drawer in my desk. It ripens June 15 th to 20 th.

My two-year-old Gonzales has such a load of fruit that the limbs are bent like rainbows.

Hon. T. M. Harwood, of Gonzales, wrote me, urging me to disseminate it. The following are extracts from his letter:

"I visited the plum tree last Saturday, and I assure you it beats anything I ever saw. The fruit is as solid on the limbs almost as grains of corn on a cob, and at the same time is large and beautiful and is sweet and delicious. Very 
small seed and sweet to the seed. No wornis or other blemish. I regard it as the finest plum I ever saw. Mrs. Miller says a tramp came along about three years ago with some very fine plums in his sack and she bought three of them for 25 cents and planted the seeds. Only one germinated and it made this tree. It is certainly different from and superior to any plum I ever saw. I suggested to call it the Gonzales Scotch Miller Plum. The people are old residents here, but from Scotland, and as all are Scotch Presbyterians, are entirely reliable."

Mr. P. T. Beach, of Luling, who first called my attention to the plum, wrote me: "I can sell a thousand trees of it around Gonzales. I am offered as high as $\$ 5$ for the few trees you have now."

The original tree bore full at two years old and again last summer at three years old. I counted 34 plums on a limb eight inches long. There was not a blemish on any of them, and about a third of them measured five inches around. $I$ have never introduced a plum in which I took so much pride.

Since the above was written I have seen the Gonzales bear two fine crops, and $m y$ opinion of it is higher than ever. My larger stock permits me to reduce the price this year from $\$ 1$ to 50 cents. Six for $\$ 2.50 ; 100, \$ 35 ; 1000, \$ 250$.

\section{What Others Think of the Gonzales Plum.}

Cedar Rapids, Iowa, June 18, 1898.

Mr. F. T. Ramsey-The specimens of Gonzales plum received. It is the most beautiful plum I ever saw. Its glossy red color and splendid keeping quality ought to make it an excellent market fruit. I congratulate you upon being the possessor of so valuable and beautiful a plum as the Gonzales.

(DR.) A. B. DENNIS.

Agricultural Experiment Station, Burlington, Vt., June 29, 1898.

Mr. F. T. Ramsey-My Dear Sir: The Gornales came in splendid condition and is one of the finest plums I ever saw. It is seemingiy of the same class as Excelsior, though of better color and seemingly of larger size. These hybrid plums are bound to change the whole face of plum pomology in a few years.

F. A. WAUGH.

Burlington, Vt., July 26, 1900.

Dear Sir: I have just returned from J. W. Kerr's place in Maryland, where he has Gonzales fruiting heavily. Mr. Kerr was pleased with it as much as I was. Very truly yours,

\section{F. A. WAUGH.}

Austin, Texas, February 20, 1901.

F. T. Ramsey-My Dear Sir: I got off of ten Gonzales plum trees that were three years old last summer sixty buckets of nice large red plums. Some of them measured seven inches in circumference. I had no trouble in selling them at a higher price than other plums. They did not ripen all at once. They commenced to ripen about the first part of June, and by the first part of July the last ones were ripe. It is the best plum I ever saw.

FRED A. GUSSEWELLE.

Mr. Gussewelle lives three miles east of Austin, and gave me the above as a reason for coming back after more trees.

Beeville Irrigated Gardens and Seed Company.

Beeville, Texas, February 20, 1903.

F. T. Ramsey, Austin, Texas-Enclosed find $\$ 5$ for which please send me one dozen Gonzales plum trees. We have this plum fruiting on the Experiment Station, and it is simply wonderful. These are for private use.

\section{S. A. MCHENRY.}

\section{More About the Gonzales.}

A few years ago the Hon. J. B. Mitchell, of Mississippi, wrote me for four hundred plum trees of my selection. I included some Gonzales. The second June after getting them he ordered 1200 trees. He lives on the Illinois Central between New Orleans and Chicago. He said he shipped all his plums in berry boxes, crated, and the cheapest varieties brought $\$ 2.25$ per crate, but all the Gonzales brought $\$ 3$ per crate. He declared if his trees were to die right then that he had made a good investment in buying them.

Last winter he got 1500 more trees. On June 29, 1903, he says: "C. $\mathrm{H}$. Weaver \& Company, the well known Chicago commission merchants, wrote me, as a market plum, the Gonzales has no equal.".

IS WVE GO TO PRESS: "Jume 27th. Can I get 1000 fronzales next fall? Full year-old trees-not June buds. J. B. MITCHELL." 
Gonzales took first premium at the World's Fair, scoring more points than any fruit of any kind.

HALE (J.). Rapid-growing tree; bears young; fruit large, red, very sweet. June 1st.

HAPPINESS (J. X. W. G.). The late Joseph Breck had a seedling come up in his plum orchard ten years ago and it bore at two years old and has borne every year since. It shows plainly to be a cross between a Japan plum and one of the Wild Goose family. He gave me some grafts to test under total restrictions, and ever since they commenced to bear I have been trying to buy the right to sell it, but did not make such arrangements until last summer. He realized its ralue, and all the time thought of growing it exclusively. The tree is one of the handsomest that grows; leaves very large; the sun never burns a plum. The fruit is borne well insile the tree, so the limbs are not pulled down out of shape. The fruit is very large, often measuring six inches around; color glowing red, and in quality it is rarely equaled. It bears full, but does not over-bear. so has no off years. If there is a better plum than Gonzales, it is Happiness. I introduce it, believing it will bring happiness to thousands of homes. This is the plum that was exhibited without a name at our State Horticultural meeting in 1903, and which. I believe, attracted more attention than any other fruit on exhibition. It will elicit testimonials as soon as it is introduced. Philosophers say happiness is something that can not be bought; it is not so now. Price $\$ 1$.

Denison, Texas, June 17, 1904.

Happiness plum received $\mathrm{O}$. $\mathrm{K}$., and we find true happiness in saying that it is large, firm, liandsome, good, of the Abundance type, and, being later, it is a fine succession of that valuable kind. Many thanks for samples.

\section{T. V. MUUNSON \& SON.}

HYTANKIO (J.). Large, dark red, very firm. July 10 th.

INDIAN CHIEF ( $T^{*}$. G.). Large, red; has a little of the flaror of the large, native wild plum. Tree strong grower and bears enormous crops very joung. No orchard is complete without this. July lst.

JUICI (J. X. IT. G.). A cross between Botan and Robinson. Medium to large, turns first yellow, then red; enormously productive. July 5th.

KELSEY (J.). Very large, lieart shaped; first turns a translucent green, then red; does best on sandy or hillside land; fine quality. August.

ICCARTNEY (C.). Of Texas origin; large, pure, yellow; ripens in May with the very early plums. It surprises all who plant it. Price, 50 cents.

IIANARD (J. X.). Introduced for Mr. Burbank, the originator, by a Pacific nursery in 1903, and sold strictly at $\$ 2.50$ each. Then I visited $M r$. Burbank in the summer, he told me he considered it on all points far superior to any other plum he had produced. The following is his description: In size it is very large, often measuring seven and one-half inches in circumference. Forin nearly round, slightly flattened at the ends, of richest crimson purple, deepening to royal damask as full ripeness is reached. Tree hardy, vigorous and compact grower. Leaves dark glossy green. Bears immense crops of even sized fruit while very young. Never fails. Surpasses all other varieties in keeping and carrying qualities. Flesh firm even when dead ripe, but melting and juicy with a deliciousness indescribable. Will command the highest price in both home and foreign markets. Price, $\$ 1$.

NONA (J. X. W. G.). Large, somewhat pointed; color bright red; flesh yellow; juicy; high quality; regular bearer; very valuable here. I consider it one of the very best. Ripens last of June.

NORJAND (J.). Tree resembles Burbank, but is a stronger grower; fruit very large, apple-shaped, pale vellow color, good quality, and exceedingly firm; does well from the Gulf to the north line of Texas, as customers are ordering more of it.

OHIO PROLIFIC (IT. G.). Medium size, red, good quality. I can truly say it never fails. My father placed it in our catalogue in 1875 ; since then it has borne every year, and only two or three light crops. July 5th.

PARSONS (A.). Dark red, of very highest quality.

POOL'S PRIDE (W. G.). Medium, oblong, very prolific. Two-year-old trees bend with fruit. Valuable on the plains and prairies. July 5th.

RED JUNE (J.). Large, round, red, firm. June 10th.

ROBINSON (C. or W. G.). Tree a fine symmetrical grower; fruit medium size and brilliant red; very firm. Year after year it has borne immense crops. One of my favorites. July.

ROULETTE (IV. G.). Like a large Tild Goose, but is corered with white dots; ripens just after Wild Goose. It scarcely has an equal for quality. July.

SANTA ROSA (.J X?). Magnificent large rich colored. Mr. Burbank's recent introduction, and he says the best of all he lias produced. Price, 50 cents. 
SATSUMA (J.). Very large, smoky red; flesh blood-red, very firm, superb flavor. Every orchard should contain some trees of Satsuma. July 10th.

SHIRO (J. X.) Very large, oblong or pointed, yellow; keeps a long time. Tree strongest grower; bears young. July.

SULTAN (J.). Very large, purplis lured; fiesh red, highest quality; bears younger than other red-fleshed plums. One of Mr. Burbank's greatest productions. July. Price, 50 ccuts.

TERRELI, (.J. X. C.). Of Florida origin. Recommended for planting in the far South.

WELCOME (C.). Medium to large, light red striped with pink. Of all very early plums I believe this will prove to be the most regulas hearer, and every drop of juice in every plum is superlatively sweet; no bitter sides on any of them. I have tested hundreds of new plums during the past three vears, and this and Happiness are the only two I offer. I have reached that point where plums must prove themselves superior to be introduced. I have had it bear three years in my black-prairie test orchard. It originated in the timber near Red River, so it has a wide field of usefulness. If you want the very best, very early, plant Welcome. It ripens in May. Price, 50 cents.

WICKSON (J.). Tree quite an upright, pyramidal grower until the limbs are bowed down with heavy crops. Very large, slightly heart-sliaped or pointed; red; flesh yellow, melting delicious. July.

WILDER (A.). Nedium size, dark red, firm. The quality is not surpassed. July 1st.

WILD GOOSE (W. G.). Nedium to large red; fine quality. It is bearing fine crops of late years. May and June.

WONDER (A. X. G. B.). A medium sized red plum, produced from seed in Hale county on the plains. Those who have had it bear in that section are wildly enthusiastic over it. I am sure it ought to be in every orchard in the Panhandle. Price, 50 cents.

WOOTEN (W. G.). Similar to Wild Goose, but slightly later and very much more productive. Introduced by my father in 1876. To meet the demand we have had to grow more trees of it than any other plum in the years preceding the introduction of the Burbank. It has made friends from Maryland to California, and is in demand down near the coast, and is one of the most popular varieties on the plains and over all the central prairies of the State. June.

\section{A List of Good Plums for Southern Texas:}

Advance, Doris, El Paso, Excelsion, Golden Beuaty, Happiness, Nona, Normand, Shiro, Wooten, Terrell.

\section{A List of Good Plums for the Plains:}

Amcrica, Eagle, Golden Beauty, Happiness, Indian Chicf, Juicy, Ohio Prolific, MeCartney, Parsons, Pool's Pride, Welcome, Wilder, Wonder, Wrooten.

\section{List of Plums that I have Budded on Mariana Stocks:}

Abundance, America, Bartlett, Botan, Burbank, Climax. Doris, Excelsior, Gonzales, Pool's Pride, Red Junc, Sultan, Welcome, Wild Goose, Wooten, Kelsey, Red October, Satsuma, Wickson.

\section{LARGE ORCHARDS: PRICES, ETC.}

I believe a fruit tree grown in this drrer atmosphere bears younger and fuller than one grown further east or north. I think I know that my robust, full, oneyear-old trees will bear enough peaches to pay several times their cost before the little soft June buds, that are being planted on account of their cheapness, bear anything. If in doubt, make inquiries-call for facts and figures from those who have tried both.

In my nursery I employ a superior class of white men and pay them about double the wages that are paid in some Eastern nurseries. but my very large stock of trees makes me foel justified in saying I can, on large lots, meet the prices of any nursery that has the reputation of being reliable.

I can name a delivered price on ten thousand or five hundred thousand trees, and, as I have the three principal railroads in the State, I can make quick delivery. 


\section{Pears.}

Prices: Extra strong, heavy trees, on Japan or Le Conte roots, 25 cents; $\$ 20$ per 100. Medium grade, 20 cents; $\$ 15$ per 100.

ALAMO. Introduced by John S. Kerr. A Grayson county seedling: probably a cross between Bartlett and an old Bergamot; fine quality; resists drouth, and bears regularly. Mr. Kerr claims it is the best of all pears for the Southwest. July. Price, \$1.

BARTLETT. Well-known old pear of fine quality. Does best in northern part of the State. July.

CANNERS. Tree vigorous, upright, ornamental; large leaves; bears very young. Fruit apple-shaped, large, russety-yellow. July and August. 50 cents.

CLAIRGEAR. Large, handsome tree; fruit large. August and September. One of the very best old pears.

CLAPP'S FAVORITE. Large red; bears young; ripens first part of July.

DUCHESSE. Very large, short-necked, fine quality. One of the universally successful good quality pears. August.

EARLY HARVEST. Tree rampant grower; bears very young; fruit very large. June and July.

GARBER. Tree most vigorous grower; fruit large, firm. Of same strain as Kieffer and Le Conte. August.

JAPAN" RUSSET. Similar to Camner's Japan. Every orchard should contain some of these because they bear regularly and are firm and fine for preserves. August. Price, 50 cents.

KIEFFER. The universal pear for America. Robust, handsome tree; fruit large and of good quality when fully ripe; one of the sure bearers; beautiful yellow color. August.

LE CONTE. Robust tree; luxuriant foliage; fruit large, attractive. The pear that led the way in South Texas.

MAGNOLIA. One of the best of the pears that contain Chinese blood; a most beautiful tree and fruit; bears young, and, while it is new, it promises to succeed everywhere. Price, $\$ 1$.

SECKEL. Noted for its fine quality. Quite successful in Texas. August.

\section{Apples.}

Price: Extra fine trees, 4 to 6 feet, 20 cents each; $\$ 15$ per 100 . Smaller size, 15 cents; $\$ 10$ per 100 .

ARKANSAS BLACK. Tree vigorous; fruit large, dark red-almost black. One of the very best late apples.

ASTRACHAN. Large, bright red, crisp; tree healthy. June 20 th.

BECKER. Originated with Dr. Becker, of Colorado county. Another Texas seedling that is proving to be one of the hardest, most prolific and surest bearers, growing in almost any soil. Fruit attractive, excellent quality. My grafts were taken from healthy young bearing trees. Stock limited. Price, \$1.

BEN DAVIS. Large, beautiful red on yellowish ground. While the quality is hardly up to that of some other apples, it is a money maker. In the northern part of the State it runs into October in ripening.

BISMARCK. A new apple from New Zealand. Very large, handsome, red; fine quality. It is creating a sensation, as it bears at two years old and regular crops each year thereafter. It seems to ştand any kind of climate. Price, 50 cents; 3 for $\$ 1$.

EARLY HARVEST. Large, yellow, tender, juicy, and of excellent quality. July 1st.

GANO. Large, smooth, deep red, attractive, good; bears young, annually, and prolific. Some apple growers claim it is the same as Black Ben Davis. It seems to be of equal value. Ripens late.

HELM. I am proud of my collection of different fruits, and especially of my apples. I could make statements about the Helm apple I could hardly expect the public to believe. I introduce it with more pleasure and more expectancy than any apple I have ever introduced. The old mother tree has been bearing for thirty-five years down in Lee county. Suckers jerked off from around the collar of the tree and planted by the neighbors are making the same record. The greatest point in its favor is it seems to be unaffected by root rot, the disease that kills cotton, the one great obstacle in the way of apple growing in Central and Southern Texas. The fruit is of the very highest quality, bright red with cream colored flesh, and ripens through July. The trees begin to bear at two years old. Of all fruits in my catalogue, this is one 
I want all my customers to try. I named it after the owner of the original tree, but believe it will prove to be the helm that will guide Texas apple growers into the haven of success. Price, $\$ 1$ each; 10 trees for $\$ 7$.

JONATHAN. Bright red, prolific, popular market variety. Late.

LINCOLN. Introduced by Mr. Onderdonk, of Victoria county. Large, pale, green, half covered with red; flesh cream color. No apple has a better flavor; bears young and very full. One experienced orchardist who saw my trees bending with big apples wanted one thousand trees. Price, 50 cents.

MAMMOTH BLACK TWIG. Similar to Winesap, but larger. Apple growers from the North declare that fortunes can be made in North Texas by planting it. Fall and winter.

MISSOURI PIPPIN. Resembles Ben Davis, but slightly smaller, but of better quality. It often bears full at two years old. For quick returns and certain money every year, I consider it has no equal over all the plains and Panhandle. It is the apple that made Roswell famous. I examined the trees in the Slaughter orchard there. I advise Panhandle landowners to plant a section with these trees. Investigate. It ripens in the fall.

OLDENBERG. This is the delicious russet-colored apple that Queen Victoria ordered from Western New York every year. It has made a reputation over this State, even as far south as Fayette county. Summer and fall.

RED JUNE. Medium bright red in clusters. June.

RUTLEDGE. One of a number of apple trees planted in Williamson county forty years ago by Captain IV. P. Rutledge. The spread of the tree reached fifty feet, and bore an annual crop of light red-striped apples. Ripens in the fall. Price, 50 cents.

SHOCKLEY. Large, productive, bears young; light yellow overspread with red. Fall.

STRIPED JUNE. One of the best old early apples; crisp; beautiful red. June and July.

SUMMER QUEEN. A popular, large, yellow apple, slightly blushed and striped. July.

TALBOT. An old seedling in Williamson county. We have been growing it for over twenty years. Our burning sum seems to have no effect on it, as it does not lean from the wind. Greenish yellow, nearly covered with red; flesh rich cream color, deliciously flavored. August and September.

WINESAP. Medium size, solid red, highest quality; always in demand. My Erath county customers have sent me some of the largest and best I have ever seen. Fall.

YELLOW HORSE. Known throughout the South as the best all-purpose summer apple. Large, yellow, sometimes with red blush; firm, splendid for eating, cooking and drying. July 15th.

YELLOW TRANSPARENT. Very early; above medium size; good, productive. June and July.

\section{Crab Apples.}

These pretty little apples do well on almost all kinds of land. Often we have seen them growing to perfection when other apples failed entirely. Price, 20 cents.

FLORENCE. Bears in clusters; yellowish, splashed and striped with red. July.

TRANSCENDANT (Siberian). An attractive yellow color, splashed and striped with red; bears very young and annual crops thereafter. We value it highly for preserves. Buds and blossoms exquisitely beautiful. Ripens in July. The best of all crabs.

\section{Apricots.}

We want again to impress upon our customers the importance of planting apricots where they will not be cultivated except with pick or spading fork during the first year after they have been planted. A tree planted in the back yard, or in some odd corner about the place, will bear three or four times as much fruit as it would if planted out in the orchard and cultivated. Plant a dozen trees on such locations; they will be productive, landsome, and will live to be very old, perhaps attaining the age of thirty years. Prices: Strong, one-yearold trees, 25 cents; $\$ 20$ per 100 .

BLENHEIM. One of the very earliest; has borne many profitable crops around Austin. May.

BUDD. Strong, upright growing tree. Fruit almost white. June. 
CLUSTER. Originated in our orchard, from Russian seed. Original tree has never failed to bear since it was three years old; of beautiful symmetrical growth, very vigorous and hardy; an enormous bearer. Fruit medium-sized, Jellow, with occasional fleck of red, and of excellent quality. Blooms late; has passed through six freezes in one season aiter blowming, and still produced a heary crop of fruit. June 15 th to 30 th. Price, 50 cents.

EARLY GOLDEN. Large, beautiful, yellow, delicious. May and June.

GOLDEN DROP. Medium size, bright. One of the very best bearers. May. HELMSKIRK. Tree very hardy; a regular bearer; good quality. May and June.

MOORPARK. Iarge; orange witl red cheek; productive. June.

ROYAL. Early, large, fine color and flavor. I received one order from California for twenty thousand trees.

SHERIDAX. This is a seedling in the rard of Mrs. Sheridan, of McCulloch county, right on the higl prairies. The tree has borne every year since it was three years old. For several years my salesman in the county has mailed me each year samples of the fruit. It is large, of a beautiful yellow color, and of most delicious flavor. It has borme several times when all other varieties in the country around it failed. Knowing that apricots are not profitable on some orchard locations. I hesitated in introducing it until the demand could be resisted no longer. I feel safe in advising all of $m y$ customers to plant a ferr trees. Price, 50 cents.

\section{Figs.}

Figs should be planted more extensirely. Do not let the sprouts or suckers grow, and prune the trees so as to have clean bodies at least two feet high. Such trees will bear fuller and will stand much colder weather than if the sprouts are allowed to grow. Price, 2j cents each; \$1S per 100.

BROTI TURKEY. Large, rich brown. Latest fig. October.

BRUNSTICK. Very large, bluisl purple.

CALIFONRIA BLACK. Robust. Succesful over Texas.

CAPRI (Male.) To plant near Smyrna when the fig wasp (Blastiphagus) is introduced.

CELESTIAL. The common little blue fig. None are sweeter; very hardy. Perhaps the best for Central Texas.

ETERBEARING. Yellowish green. nedium size, roung persistent bearer.

HIRTU DU JAPAN. Tree very dwarf and compact.

LEMON. Large, yellow, sweet.

MAGNOLIA. Very large, pale green or white; shape varies from ordinary fig shape to very short or flat; always bears at one year old, and. if frozen, will bear on the young wood the first year. In some sections it is called Neverfail.

SMIRNA. Large, pale color.

WHITE ISCHIA. Pale green or transparent; deliciously sweet. Should be in every fig orchard.

\section{Prunes.}

Commencing west of Fort Worth, prunes are valuable on most locations all the way west to Pecos City and north through the Panhandle. Price, first-class trees, 25 cents each; $\$ 20$ per 100 .

GER.MAN. Flesh firm, greenish, very sweet.

GIANT. A prune of great size produced by Mr. Burbank; raluable, prolific. GOLDEN. Light golden color, exquisite flavor.

TRAGEDY. Grows far South; rich, sweet; almost a freestone.

ITALIAN. Suited to the South. Tery popular.

\section{Cherries.}

Not generally valuable in Central and South Texas, but becoming popular toward the Panhandle. Price, 40 cents.

BALDIVIN. A new Kansas variety of more promise and attracting more attention than any cherry ever introduced. Price, 75 cents.

EARLY RICH'IOND. An old popular variety. Early.

ENGLISH MORELLO. Another old standard variety; later.

MONTMORENCY. Very large. In great demand for large commercial orcliards. 


\section{Nectarines.}

Will flourish on any land adapted to the peach, and with the same cultivation, etc.

JUMBO. Originated in Burnet county from a peach seed. On favorable locations it grows very large. A decided improvement on the old Red Roman. Price, 25 cents.

NEW WHITE. Large size, white skin and flesh. Price, 25 cents.

RED CLING. An old seedling in Fayette county of great value. Free from all insects. Large, sweet. Price, 50 cents.

SUNSHINE. Native yellow freestone. Extra good.

ULIT. A new Austin seedling. A pure cling, consequently almost proof against the attacks of the curculio. A big step forward in real value. Price, 50 cents.

\section{Japan Persimmons.}

Some of these should be planted by every family. The fruit often measures ten inches in circumference. They ripen in August, September and October. The trees bear young, and are very ornamental. Price, 35 cents each; 25 cents when order calls for 100 trees in all.

HACHIYA. Very large, oblong, pointed; flesh yellow; skin red.

HYAKUME. Large; skin orange red; flesh brown or dark; very sweet. It is free from astringency before it is ripe.

OKAME. Large; carmine skin; clear yellow flesh; few seed.

TANE NASHI. Orange red; yellow flesh; generally seedless.

YEMON. Large, flat, tomato shape; red skin.

\section{Quinces.}

The quince is very valuable for preserving, and for this purpose brings high prices in market. The tree is of dwarfish habit, and fine grained, close growth. Should have a top dressing of stable manure about the roots every year. The little care required is amply repaid by the rich fruit. They do best when not cultivated deep, and like a location like a back yard, but weeds and grass must not be allowed to grow around them. The north side of buildings preferred.

Price, 35 cents. I have Meech, Orange and Champion.

\section{Mulberry.}

Every farm should have mulberry trees about the back yard and where the chickens run. They make a quick, long-lived shade. They commence to ripen before peaches or plums, and continue six or eight weeks. Price, 25 cents. (For non-fruiting mulberry, see shades.)

ENGLISH (Black). In appearance the tree is like a luxuriant Multicaulus mulberry. Bears at two years old; berry large. Ripens in April and May.

HICKS. The old, standard, everbearing variety. Tree rery hardy; strong, awkward grower.

MUNSON. Russian type, introduced by Mr. Munson, who says it is one of the largest, most prolific, and best of all mulberries.

TRAVIS (Everbearing). The leaves are of the style of our large, wild mulberry, but the tree is more symmetrical and compact, making it the very best for shade. I emphatically claim it is the best of all mulberries for fruit. It is very large and sweet, and borne in greatest profusion. The original tree stands in Travis county.

\section{Fruiting Pomegranate.}

Pomegranates should be planted around every home in Central and Southern Texas. The beautiful coral-red flowers, that are borne from early spring until frost, make them rank among our very best ornamental trees. If the suckers are kept down and the trees given a clean, single body, they are much more fruitful, and the fruit grows large. One soon grows fond of them.

EVERBEARING. Compact growth, profuse bloomer. Price, 25 cents. 
JACOBSON. A Texas blackland seedling. The tree has a weeping habit. Fruit large with a refreshing flaror superior to all others. As soon as this variety becomes known, it will be universally planted. Price, 50 cents.

SPANISH RUPY. Profuse young bloomer and bears young; fruit brilliant red. Price, 25 cents.

1)OTBLE FLOWERING. Pink, white, and red--(See flowering shrubs.) Price, 35 cents.

\section{Grapes.}

The Munsonian system of training is cousidered one of the best. Set a post, $6 \frac{1}{2}$ feet long 2 feet into the ground, placing a cross-arm 2 feet long at top. Place these posts every 20 feet along the rows, putting two strings of wire upon the end of cross-arms. Tie the single stem of vine up between these wires, the branches of the vine formirg on these two wires an arbor, shading the fruit and vine, and easy to be sprayed. Prune heavily in February, before the sap starts. A straight stake by each vine is sufficient for the first year. Except where noted. Price, 15 cents; $\$ 12$ per 100.

BLACK SPANISH. Wedium to small black berry; bunch large; little or no pulp; fine quality when thoroughly ripened. Good vine for arbors also. July.

BRILLIANT. A most beautiful red grape of high quality. One of Mr. Munson's introductions, and a favorite. Price, 25 cents.

CARMAN. Another of Mr. Munson's hybrids, dark red, fine quality. For hardiness and regular crops, I consider this the equal of Herbemont and Black Spanish, and it is larger. I advise every person to plant some vines of it. Price, 25 cents.

CHAMPION. One of the earliest; large, round, blue-black; vigorous. June.

CHASSELAS. Golden color; large bunch of Vinifera or California type. Its best range is the western part of the State, and it is making a record on the coast.

CONCORD. Large blue or blue-black. Perhaps no grape is successful over so wide a range of territory. July.

DELAWARE. Medium to small, with very thin, tender, red or pink skin. One of the most delicious of all grapes. While the vine is not a fast grower, it lives and bears where some others fail. June.

GOETHE. Large, oblong, pale amber color; sweet. July.

HERBEMONT. Medium size, round, black; not good when first it turns black, but delicious when thoroughly ripe; vine robust and long lived. July.

MALAGA. Very large bunch and berry; white or pink-white. Chiefly valuable in Western Texas.

MISSION (El Paso). Medium size, black, deliciously sweet. Its best range is westward.

MOORE'S EARLY. Vigorous vine, fruit large, black; very early. June.

NIAGARA (White Concord.) Large, amber-white berry; good quality. Succeeds reasonably well in all sections of the State. July lst.

SULTANA (Seedless). A delicious, tender, table grape, but, like all Vinifera varieties, belongs westward.

THOMPSON'S SEEDLESS. Vines we sold in Arizona and New Mexico are proving of great value. Probably good in the Barstow and Pecos section.

SPECIAL NOTICE.

I PAY THE EXPRESS to any express office in Texas when order amounts to $\$ 3.00$, and to any point in $U . S$. if order amounts to $\$ 5.00$, and REPLACE AT HALF PRICE all trees that die within one year. 


\section{Blackberry.}

No farm or city garden should be without a patch of blackberries. They bear one year after they are planted, and annually thereafter. Of the six varieties I sell, all are of Texas origin. They cover a season of near two months. In addition to the profit and pleasure of eating them fresh, they supply a family with the very choicest of jams, jellies and preserves; and nothing is nicer or more easily prepared for canning. All these can be put up during pleasant spring weather. They keep better than any other fruit. The enormous yield elicits exclamations of surprise from all when they first see them. All these remarks apply also to dewberries and the crosses between the two, including the McDonald and Haupt.

DALLAS. The standard in Texas; combines all good points; large; fine quality; productive. Early to midseason. Price, 50 cents per 10; $\$ 3$ per 100.

JORDAN. Another North Texas product making a great record everywhere. Bush very vigorous; bushels of large, sweet berries; ripens after Dallas in May and June. Price, 75 cents per $10 ; \$ 4$ per 100.

ROBISON. Originated in Eastland county. In great demand in north portion of State; ripens late. Price, 75 cents per $10 ; \$ 4$ per 100.

SPALDING. Originated in Gonzales county by the late Mr. Spalding. Among many seedlings he soon recognized its value for South and Central Texas. Bush strongest grower of all and enormously productive. Fruit medium size, very sweet; perhaps the earliest of all pure blackberries. Unless the vines, both old growth and young, are cut off at top of ground and a second growth allowed to grow after the fruit is ripe each spring, the fruit will be rather small. Let every one plant some. Price, 50 cents per 10; \$3 per 100.

THE MOST IMPORTANT FACT IN CONNECTION WITH BERRI CULTURE is this: The last of July on all dewberries and on Haupt and McDonald. cut all tops ofi at the ground, both old growth and young. Pile or rake the vines and burn them on the ground as soon as dry. On some years this treatment seems good for pure blackberries also. (They should be cut as soon as the fruit is picked.) You can then plow close up to the stumps with a sweep or other plow, thus saring the tedious work of getting the weeds and grass out of the rows when left standing. New growth will spring up at once, and the berries the next season will be very much larger, nearly doubling the number of of boxec the plants would produce if left unpruned. The rule is something like this: Half the work, double the yield. I do not know how far north this method is good, but it is certainly best for the south half of the State. It renews rusty blackberry patches. Try half of each row and see the difference. On some vines I use a two-horse mowing machine; on others a brush scythe or sharp hoe.

\section{Dewberry.}

All that has been said about the value of blackberries may be said of dewberries. They ripen earlier as a class. In cultivating, the vines are pushed around on the row forming the mat. I do not advise trellising or tying up the vines, for the nearer the ground a berry grows the larger and sweeter it is. I plant in rows about four feet apart, and the plants may be about the same distance apart in the row. Some set them closer. For number of plants on an acre, see last page of catalogue. I can not name a fruit so absolutely sure to bear every year and so perfectly free from insects and disease. Being natives of our black and sandy prairie and timber lands, we should have looked to them for profit long before we did. Price, 50 cents per $10 ; \$ 3$ per $100 ; \$ 20$ per 1000 .

AUSTIN-MAYES. Robust, short vine; fruit very large. Every person, ever renters can afford to and should plant some. They bear a big crop one year after they are planted. Since tlis berry was discovered in Denton county about twenty years ago it has produced a full crop each year. Ripens in May.

CHESTNUT. From Johnson county. Early. May. Productive. Extra quality.

ROGERS. Originated near Alvin, where it is commercial favorite; large; perhaps the earliest. It seems to prefer sandy or river bottom land.

SAN JACINTO. A large berry I found near Austin. Perfectly successful on all locations; very early-never later than 21st of April. Price, 75 cents per $10 ; \$ 5$ per 100 .

WHITE. I have fruited several varieties of White. This I found near Austin. Very much more productive than others, and of larger size. April and May. 
OTHER VARIETIES. I have over forty varieties of pure dewberries from different sections of the United States, but chiefly from Texas. All are scarce. I will select you five lundred plants, containing twenty varicties, for $\$ 15$; one thousand plants for $\$ 25$. In these, I pnt in more frcely of the best tested varieties. You can spend the money in a way that is so sure to bring you health, happiness and profit eacl year as long as you live.

Mr. E. P. Norwood, who lives twelve miles from Austin, met me at our Farmers' Institute and took me aside and made the following statement. I vouch for its truth: "You remember I got a thousand dewberries from you a year ago last February. This spring when they began to bear one of my renters proposed to pick and sell for half the money. I agreed to it, but I was to pick all I wanted and I am sure I used all the plants cost. He turned me over $\$ 67.50$. So from one-third of an acre I have received average cotton rent twenty-two years and a half in advance on a whole acre."

\section{TlcDonald Berry.}

It is hard to decide whether this is a dewberry or a blackberry. It bears in clusters like a blackberry but tips like a dewberry. On ground on which fruit trees and some blackberries turn yellow, this berry is perfectly green. I noticed this a hundred yards away. It was introduced by Mr. Kirkpatrick, of McKinney. I sell at his price and give part of his description: "Large, juicy, of best quality. Earliest, hardiest, most vigorous and most productive of all berries here. This is a new berry, a cross between the blackberry and the dewberry. It stands up like a blackberry, and 'tips' like a dewberry. It is incomparably more productive than any berry fruited here, one plant producing more fruit than a half dozen plants of any of the older sorts. Twenty quarts of fruit have been gathered from a single plant. Its bright green foliage is held through the hottest summers and is nearly or quite evergreen. Among its admirable qualities is its earliness; the fruit is ripe one week earlier than the Austin or any other good blackberry. Planters here, who have thoroughly tried this berry, would not exchange it for any other. It was discovered in this county near Wiley, Texas. We introduce it with confidence that it will prove a valuable acquisition." These crosses between blackberries and dewberries fill with amazement those who see them bearing. A banker of Austin who was looking at a row of them on my test grounds last year watched a couple of boxes picked off of one vine and then made a careful estimate and said a solid acre like them would yield at one picking $\$ 2200$ worth of berries at the price then prevailing, $12 \frac{1}{2}$ cents a box. Price, 75 cents per 10 ; $\$ 4$ per $100 ; \$ 25$ per 1000 .

\section{The Haupt Berry.}

The late Colonel Haupt, of Hays county, spent much time and money in collecting dewberries and blackberries. He got one (probably from Wharton county) that eclipses everything. It is certainly the most valuable variety of fruit of any kind. A few years ago I paid a fancy price for all the plants he would spare. I found them robust growers, never turn yellow, ripen early in April and May, and best of all they never have a faulty or poorly filled berry. They are of good size and of the very highest quality. They keep for a long time after turning black.

They are productive beyond description. My foreman declared that the best vine had forty quarts on it. I hardly think so, but it looked like it had.

It has those characteristics that denote it is a cross between a dewberry and a blackberry. There are two or more slightly different strains mixed.

Recently, for $\$ 900$ I secured from Mrs. Haupt the entire crop of plants from their little patch for three years, being practically all there are in existence. It is the best thing I have ever disseminated. It is an evergreen like a Southern dewberry, so can be planted in the summer, as I have found out. The small vines in the picture were tiny suckers planted in June.

I ding over the Haupt patch this year, and from the 8 th to the 17 th of August planted about 30,000 plants, and have been unable to find a single one dead.

We pledge the thirty-five years' experience and reputation of the Austin Nursery on the unequaled value of the Haupt. We personally commend it to all our friends and customers. Price, 25 cents each; $\$ 2$ a dozen; $\$ 8$ a $100 ; \$ 40$ a 1000 .

\section{Gooseberry.}

Leading varieties. Price, 25 cents; $\$ 2.50$ a dozen; $\$ 18$ a 100. 


\section{Currants.}

Best varieties. Price, 20 cents each; $\$ 2$ a dozen; $\$ 10$ a 100 .

\section{Raspberry.}

KANSAS. This is a fine, large, black raspberry, so far superior to other varieties that I sell no other; ripens in May. Price, 75 cents per $10 ; \$ 4$ per 100 .

\section{Strawberry.}

Long summer drouths are hard on strawberries. Frequent cultivation or careful mulching is necessary. They do best on new land. Price, 25 cents per 10; $\$ 1$ per $100 ; \$ 7$ per 1000 . tory.

EXCELSIOR. Very early; has proven profitable over a wide range of terri-

LADY THOMPSON. A great favorite with all growers. Midseason.

KLONDYKE. From Alvin to Illinois praised by all growers.

OTHER VARIETIES. I handle several other leading varieties.

\section{See my offer on the best collection of Dewberries on earth. Page 16.}

\section{Nut Trees.}

PECANS.

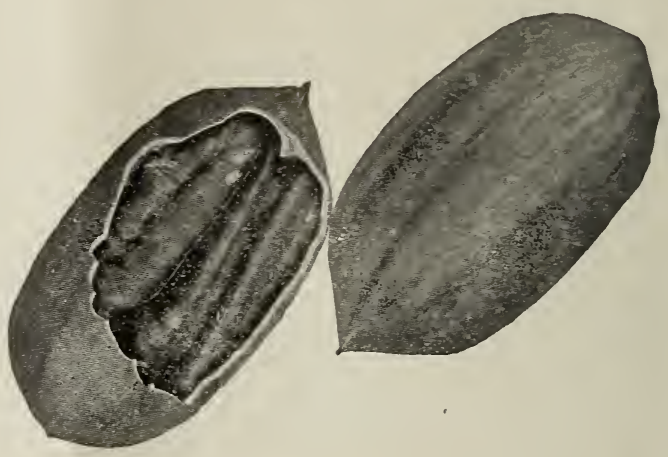

No class of trees is growing in popularity so fast as are pecans and other nut trees. If you have land on which pecan trees do well, plant some by all means; and, if you are planting an orchard of ordinary fruit trees, if you plant a pecan for every other tree in every second row, it puts them about the right distance apart ( 36 to 40 feet). They reach a profitable bearing age about the time a peach and plum orchard becomes exhausted.

ADVICE. Never destroy a pecan tree. If you have trees that bear irregularly or poor nuts or ordinary nuts, cut three-fourtlis of the top in the winter. The strong shoots that will come in the spring can be budded in the summer with fine sorts, and the buds may be bearing in two years. Learn to bud. Write to the Department of Horticulture, Washington, D. C.. for free Bulletin on budding pecans. Some varieties can be sold for about 50 cents a pound.

While all seedlings will doubtless bear nuts that will be profitable, they do not come true from seed, but, if one is not able to buy the budded or grafted trees, let him not fail to plant seedlings. By the time they are large enougin. he may learn how to bud them. Pecans are harder to buil successfully than are other trees, so have to be sold much higher. Plant some for shade trees.

SEEDLING PECANS. Grown from the finest nuts obtainable (native). They are certainly the best of all seedlings. Sometimes the varieties brought from the East or Southeast do not mature plump kernels. Price, 1-year trees, 20 cents each; $\$ 12$ per 100 ; price, 2-year trees, 30 cents each; $\$ 18$ per 100.

GRAFTED PECANS. Several named varieties; best in Texas. Louisiana and Mississippi.

Price, 1-year bud, usnally o to 12 inches on a stock, 1 foot high. \$1 each; 2 to 3 feet, heavy, carefully dng. $\$ 1.50$ each.

DAISY. Long, light colored, thin shell. Introduced by Mr. Locke.

FROTSCHER. From Louisinn. Large, fine. It is this variety that was planted on Governor Hogg's grave. 
HALbERT. A native of Coleman county. Introducerl by Mr. Halbert. Scores high on every point.

HOLLL.S. Very large, plump. The old tree in San Saba county has rarely failed to produce a crop.

OLIVER. The largest pecan 1 have ret seen. I bought the right to introduce it. The old tree is very large and stands in Kimble county and has produced is bushels in one crop, and is a constant bearer. Very large luxuriant leaves. Price, \$2 eacll.

SAN SABA. Introduced by Mr. Risien, of San Saba county. Medium sized, shell extremely thin, quality very best. I grafted tree bought from Mr. Risien several years ago is bearing on my place on common black land. Price, $\$ 2$.

TEXAS PROLIFIC. Another of Mr. Risien's. I fine pecan noted for bearing very roung everywhere. I have seen thre-year-old burls scarcely above my head with sereral clusters of pecans. Price. $\$ 2$.

JAMES, MONEYMAKER, PABST, PRIDE OF THE COAST, STUART, TAN DEMAN. These are the favorite Jouisiana and Missis-ippi varieties. All are large and fine.

OTHERS. I have a few trees of several very fine new Texas sorts of extra value.

MEDINA ALMOND. A seedling in Medina countr. My attention was called to it by one of my salesmen, Mr. Christal. It is as fine as any imported soft-shelled almond, and has been bearing regularly for a number of rears. II two-year-old trees have not borne, but bloomed very much later than any of the other six rarieties in my orchard. I really believe it opens a new industry for a large scope of country. Price, 50 cents each; 10 trees for $\$ 4$.

PRINCESS ALMOND. Robust tree; not a regular bearer, but the almonds are of fine quality. Price, 25 cents each.

SULTANA ALMOND. A standard commercial rariety, similar to abore. Price, 25 cents each.

BLACK WALNUT. The nuts are not commercially valuable, but ther should be planted for shade and timber and for stocks on which to graft English walnuts and some new hybrids that will be offered in a few years. Price, small 1-year trees, 10 cents; $\$ 6$ per $100 ; 3$ and 4 feet, 25 cents each; 5 to 6 feet, 40 cents.

ENGLISH WALNUTS. Excepting pecans, this is perhaps the finest nut that grows. It is somerhat affected by our summers and by sudden freezes. Price, 25 to 50 cents; from 1 to 4 feet.

FRANQUETTE and MAYBETTE TALNUTS. These are special strains of the English or Persian Walnuts that seem perfectly at home in our climate. The quality and shell are equal to the finest English. Price, 1 to 2 feet, 75 cents; 2 to 3 feet, $\$ 1$.

\section{Lemons, Oranges, etc.}

WONDER or PONDEROSA LEMIXN. Fruit sereral times as large as common lemons, of good quality. Can be grown in tubs. or out doors, if proteted from frost. Ornamental. Six to 12 inch, 40 cents; 1 to $\neq$ feet, 50 cents to $\$ 1$.

SATSLMA ORANGE. Budded on Trifoliata. A Japanese orange quite hardy orer Southern Texas. Of real value; good qualits; bears roung. Thousands are being planted. Price, small buds. 50 cents: $1 \frac{1}{2}$ to 2 feet, 75 cents; 2 to 3 feet, $\$ 1$.

CHINESE JUJUBE. Tree slightly resembling prickly ash; very hardy. Fruit chocolate colored, size of a large olive. Somewhat resembles a date in taste; ripe July and August. We greatly enjor this fruit. Every one should plant a few trees. They like a clean backrard where they are not cultirated but will grow anrwhere. Price, $1 \frac{1}{2}$ to 2 feet, 40 cents; 2 to 3 feet, 60 cents; 5 to 6 fet, \$1.

THE TEXAS BELL TOMATO. A cross between a large tomato and the small, hardy volunteer variety. Bears all summer. Does not rot. I am the sole introducer. Small paper seed, 50 cents. 


\section{ORNAMENTAL DEPARTMENT.}

The country or suburban house that has it shade trees, its slirubbery and its flowers has laallowed memories to win back the hearts of those who wander from its walls, and brighten their darkest hour. The home that has no green spot and shade at its door will not be so endeared to its inmates as it otherwise would be. The condition of rural improvement is an index to the taste and general growth of refinement in any community. But ornamental planting not only increases the beauty but adds greatly to the value of farms and homesteads.

PLANT PROPERLY. To one who observes the effects of trees and shrubs on a landscape or small home grounds, many purchases seem a waste of money. It takes a volume to name all the delicate details. Have a grass lawn in front of the house. Put large trees in rear of house and at sides principally. Put roses, evergreens and shrubs against the side fences and in careless, easy, restful masses or groups toward the right and left. As much as possible, avoid straight rows and geometrical beds or designs.

PLANTING PLANS. If you are going to spend $\$ 100$ in beautifying your grounds, spend part of it for advice and plans from a competent landscape gardener of the modern school. Generally, I can refer customers to such. Sometimes I may have time to attend to such myself. At all times I will take pleasure in giving advice. I take great interest in beautiful effects, and believe I can name a collection of hardy ornamentals that is the very best for our climate. I collect and grow some valuable native shrubs, etc., and have in small quantities many sorts not named in catalogue.

\section{EVERBLOOMING ROSES.}

Some roses do best when budded on hardy stocks. Do not allow the suckers to grow below the bud. For outdoor planting, I consider these the cream of the world. All are hardy outdoors, and will bloom from April until frost if given sufficient attention to keep them growing. I sell large, fine bushes that stand at least one year in the field after coming out of the greenhouse. and all have bloomed and will commence blooming in early spring after planting. The best time to transplant roses is near the first of February, but they can be safely moved from November to April. Price, 35 cents each; 3 for $\$ 1 ; \$ 4$ a dozen.

AMIERICAN BEAUTY. Red, large, fragrant. In a way it has no equal. Fine large plants at common price; extra heavy plants, 50 cents each.

BABY RAMBLER. Dwarf. Most constant bloomer. Brilliant clusters of 15 to 30 roses. Hardy.

BALTIMORE BELLE. Pink; hardy everywhere; spring bloomer, Fine for permanent arbors. Will perhaps live a hundred years.

BON SILENE. Pink; exquisite buds.

BRIDE. White, sometimes shaded with pink when grown outdoors.

BRIDESMAID. Pink; similar to Bride, but a dark pink.

BURBANK. Very bright, light and dark pink. Wonderfully profuse and persistent bloomer; new; sure to become universally popular.

CHAMPION OF THE IVORLD. Pink; robust grower; extra hardy; half climber.

CLOTHILDE SOUPERT. Medium in size; profuse; white with distinct pink center.

CLOTH OF GOLD. Clear golden yellow; climber.

CRIMSON RAMBLER. Brilliant red in great clusters; early in spring; beautiful foliage; climber.

DINSMORE. Dark red; very large.

EMPRESS OF CHINA. Cherry red; hardy; climber.

ESTELLA PRADEL. Pure white; climber; one of the most constant bloomers of the good climbers; buds elegantly formed.

ETOILE DE LYON. Yellow; robust; one of the most constant bloomers.

FRANCES E. WILLARD. Pure white, large, fine; worthy of being named after "the greatest of women." Price, 50 cents. 
GEN. JACQUEMINOT. Blood-red; blooms for six weeks in the spring; hardy.

GEN. MedRTHLR. strong grower, tall, large red.

HELEN GOULD (Red Kaiserina). A dark rich pink; long stems; most per. sistent bloomer. It stands high at the top of my list of favorites. It is also known as Baldwin.

CLIMBING HEIEN (iOLLD). One of the fine-t pink climbers.

KAISERINA. White. Long, pointed buds and full when open and lasts well; long stems. For an outdoor white rose it has no rival.

C'LIMBIXG K.AIERIXA. Elegant pure white.

JAA FRANCE. Pink; large; full; fragrant; universally popular; hardy.

RED LA FRANCE (Duchesse of Albany). Similar to above; red; tall bush.

WHITE LA FRAXCE. Very pale pink; hardly as full as La France.

LA MARQUE. Pure white; rampant climber; a standard all over the South.

LA TOSCA. Very much like La France in every particular. but a freer blooming more robust bu-ll.

LIBERTY. Very large; slowy; red.

MADAME MASSON. Very large and double; intense red; unitorm in size and color; extra long stems. In its grand glory, the equal of any of the other leading lybrid perpetuals, but will produce flowers about twice as many days in a year. For a red rose I plant it first. It will make you happy.

MADAME TESTOUT. Soft pink; profuse.

MALMAISON. Light pink; extremely double; fragrant; stiff stems; beautifu] foliage.

IWHITE MALMAISON (Crown Princess). Snowy white; very double; crimped petals.

MARECHAL NEIL. Most popular of all climbers; rich deep yellow; fine plants on own roots, and budded on hardy stock at common price. A few extra heary with 5 to 10 -foot canes cut back 50 and 75 cents.

RED MARECHAL NEIL. Soft, lovely red; otherwise fully equal to the yellow. Price 50 cents.

PINK MOSS. Most beautiful in bud and when half open; hardy.

WHITE MOSS. Like the pink, but pure white.

MARTHA WASHINGTON. Pure white, in clusters; not very large, but always in bloom; either bush or climber.

METEOR. Velvety red; justly popular.

CLIMBLITG METEOR. Glowing red; robust; climber.

PAPA GONTIER. Intense red. Its long sharp pointed buds, that linger and wait for you to cut them, have no superior.

PAUL NEIRON. Rich pink; extra large; full; fragrant. One of the tallest growers. No finer rose while it blooms in the spring.

CLIMBING PACL NEIRON. Flower similar to above; vine a big, rugged climber.

PEARL OF GARDEN. Rich, golden yellow.

QUEEN'S SCARLET. Fiery red; so profuse that the whole bush glows.

R. E. LEE. Nasturtium yellow; elegant.

REINE MARIE HENRIETTE. Fine red climber; successful on all soils.

SAFRANO. Free bloomer; color changes from apricot yellow to fawn; choice buds.

SLVEN SISTERS. Color raries from very light to dark pink; great clusters of flowers in spring; bush hardy everywhere.

SOLFATERRE. Peculiar, rich copper or bronze shade.

SUNSET. Golden amber, shaded with crimson.

TIPLITZ. Most brilliant red and alwars in bloom. In the nursery, this row is the most striking of all.

VICK'S CAPRICE. Pink with white stripes.

W. A. RICHARDSON. Most intense yellow in existence; very long, pointe:1 buds; bush or climber.

WHITE RAMBLER. Hardy annual; pillar or climber.

YELLOW RAMBLER. Persistent b!oomer of the Ramblers; hardy.

\section{Hedge Roses.}

MeCARTNEY. Single white flowers. Bright evergreen foliage. They make a fine background; long lived. Price, 25c: $\$ 20.00$ (a 100 .

RAISEI: HEDGE ROSE (see Hedges). \$10.00 (c) 100 . 


\section{BULBS, LILIES, ETC.}

These are so easily grown and produce such a gorgeous lot of colors that no home should be without them. These can generally safely be left in the ground over winter, or they may be taken in and kept dry until early spring. They should be transplanted at least every two years for best results.

ANGEL LILY (Crinum fimbriatulum). See photo. I consider this the most valuable of all the list of bulbs, except the Mexican tuberose. Large bulbs, 30 cents; 10 for $\$ 2.50$.

AMARYLIS JOHNSONII. The gorgeous red in early spring. This and Angel Lily do not have to be transplanted or divided for many years. Price, 25 cents. CANNA. They range in color from bright yellow to rich crimson, and include such varieties as Burbank, Italia, Flamingo, Alphonse, Bouvier, Alemania, Florence, Vaughn, Madame Crozy, etc. Price 10 cents each; $\$ 1$ per dozen.

CENTURY PLANT (Agave Americana). The Maguey or Pulque plant of Mexico. It is the king of all its family and blooms in a few years after planting. A large plant I moved into my yard the past winter has thrown up a great stately stalk 18 feet high, and is covered with luxuriant flowers; perfectly hardy. Price, according to size, 50 cents to $\$ 1$, and more for extra large ones.

GLADIOLUS. The best strains of Groff's hybrids. If you plant a thousand, you will scarcely have two alike. From April until July they give a glow of color. Price 50 cents a dozen; $\$ 3$ per 100.

JAPAN EASTER LILY (Lilium Longiflorum). Magnificent trusses of white flowers. Perfectly hardy outdoors. Take bulbs up after they bloom in spring and plant again in September. Price 20 cents; $\$ 2$ per dozen.

MEXICAN SACRED LILY (Amaryllis Formosissima). Crimson early bloomer, hardy, attractive. 20 cents each; $\$ 2$ per dozen.

YELLOW DAY LILY (Hemerocallis Fulva). One of the hardiest of all lilies. Once planted you have it always. Rich gold color, striped inside. Price 15 cents each; $\$ 1.25$ per dozen.

TRITOMA (Redhot Poker). I have five or six varieties. They bloom constantly from May until frost. Glossy stems, one to two feet high, with glowing orange-red flower spikes; very striking and attractive. Price 15 cents; $\$ 1.50$ per dozen.

DWARF DOUBLE TUBEROSE. A favorite further North and East; flowers very double. Price, 25 cents a dozen; $\$ 1.50$ per 100 .

VARIEGATED TUBEROSE. Flowers single, cream or white; leaves white and green striped. Price, 25 cents per dozen; $\$ 1.50$ per 100.

MEXICAN TUBEROSE. A few years ago a friend of mine brought me a few bulbs from the high cool interior of Mexico. After procuring all varieties I have seen advertised in the United States, I find none like it, and none that compare with it on any point. It las tall stiff stems; flowers pure white, single, delightfully fragrant, and withstand all kinds of wind and weather except hard frosts. I leave mine in the ground, but a zero freeze would kill at least part of the bulbs. They commence to bloom the 1st of June, and are a mass of white until cut down by frosts. Many carriages stop daily to inhale the fragrance that floats from the patch. It is one tuberose that never blights, and the smallest bulb blooms the first season and generally throws up from five to fifteen flower stalks. I sell the cut flowers at retail and to florists in immense numbers. I presume my tuberose patch is the most profitable piece of land in Texas. When the first flowers are open, if the stalk is cut and put in a vase of water, it increases the size and whiteness of the flowers; the first stay fresh until all the spike have opened. It improves for a week and will keep ten days. Lach town in Texas will use the flowers from a patch of several thousand bulbs. It pays to give them good cultivation and plenty of water. See photo. Price, 50 cents a dozen; $\$ 3$ per $100 ; \$ 20$ per 1000 .

PALM (Washingtonia filifera). The hardy fan-leaved hardy sort from the San Jacinto Mountains of California. Grows 20 feet. Price, smallest, 50 cents; 6 to 8 leaves, $\$ 1$.

\section{GRASSES.}

GRACEFUL GRASS. Grows three to four feet. Perfectly hardy. Graceful, fairy-like plumes. Fine for winter bouquets and decorating. All grasses should be divided every two years. Price, 25 cents.

LEMON GRASS. Grows two feet, but has no plumes. The blades when bruised are delightfully fragrant and make a tea prized by many for its pleasant odor and for its medicinal qualities. 25 cents each; $\$ 2$ a dozen.

PAMPAS GRASS. Grows five to ix feet. Its fluffy white plumes, two feet in length, make it the most striking of all grasses. 35 cents; $\$ 3$ a dozen.

ZEBRA GRASS. Three to four feet. Green with white plumes. Delicate plumes, 25 cents. 


\section{FLOWERING SHRUBS.}

These comprise the most hardy and the most constant bloomers to be found for this section. They give flowers constantly from the time the first spirea opens in the spring until frost catches the althcas, crape nyrtles and pomegranates. A few dollars' worth of shrubs, evergreens and shades adds much to the comfort, pleasure, beauty and value of a homc.

ALTHEA (Rose of Sharon). Nothing more hardy; many colors; if kept growing, they bloom constantly; pink, purple, red, variegated, and white. Price, 25 cents.

CAPE JASMINE. Beantiful evcrgreen; white, fragrant flowers; does best on sandy soil. Price, 2 feet, 50 cents; smaller ones, 35 cents.

CRAPE MYRTLE. A glow of color; pink, scarlet, and white. Price, 25 cents.

DEUTZIA. Beautiful, double, white flowers, tinged with pink. Price, 25 cents.

LILAC. Purple and white; fragrant; early bloomers; old favorites. Price, 25 cents, on own roots. (I liave the white budded on Ligustrum, which makes it bloom young and more freely. Price, 50 cents.)

MOCK ORANGE. Orange-like flowers. Price, 25 cents.

PEACH. Double flowering; crimson, pink, and white. They resemble bright, medium-sized, double roses in early spring. Price, 25 cents.

POMEGRANATES. Double flowered; pink, red, and white; also the fruiting varieties, with single coral-red flowers. Price, 25 cents.

SPIREA (Bridal Wreath). Single and double; a bank of white in spring. I have also the Blue Spirea, which is really a Caryopteris. It blooms in midsummer; fragrant; fine for bees. Price, 25 cents.

FLOWERING WILLOW (Chilopsis Linearis.) They are natives of the dry section of Western Texas and New Mexico. They bloom constantly from May until late fall, and in the extreme dry heat of summer they bloom most profusely. They grow on any soil, and are long lived. Nothing nicer for cemeteries. The lace-like flowers are about an inch and a half long, and are borne in clusters. There are three distinct colors. Purple (a lilac purple), Lilac (pale lilac, slightly mottled), White (pure crimped white). Price, 35 cents.

TAMARIX AFRICAN. The common Salt Cedar. At home on all locations from the edge of salt water to the mountain top. Price, 25 cents; $\$ 10$ a 100 .

TAMARIX. Three new everblooming sorts from Europe. My own importation. Most beautiful delicate feathery foliage. Trees symmetrical. Admired everywhere. Price, 25 cents.

PRUNIS PISSARDII. Red-leaved plum; gives variety in masses of shrubs.

\section{Beautiful Hardy Native Sh rubs, etc.}

Were I planting a yard and had to choose between natives and shrubs and trees from the balance of the world both tame and wild (leaving out roses). I would be inclined to choose the natives. They are indifferent to drought and disease. Will stand for a lifetime without care, but respond lavishly to attention. I offer some of the best.

CLEMATIS COCCINEA. Red, coral-like, bell-shaped flowers; all spring and summer. The vine comes from the root every spring, and grows eight to ten feet; very hardy. Price, 25 cents.

CLEMATIS CRISPA. Like above, but flowers are blue. Price, 25 cents.

CORALBERRY (Symphoricarpus vulgaris). Coral red berries in winter until after Christmas. Price, 25 cents.

ELDERBERRY. Trusses of white flowers in summer. Price, 25 cents.

EUPATORIUM AGERATIFOLIUM. Wonderfully fragrant white flowers, late in October and November. I have seen nearly thirty kinds of butterflies on a bush at one time. Sweetheart bush is the only common name I have heard. Price, 35 cents.

LIVE OAK. (See Shades.) Price, 40 cents.

LEUCOPHLLUM TEXANUM. Evergreen ashen colored foliage that shows quite well all the year. Several times during the summer when a rain comes after a drouth the bush is almost a solid mass of pale lilac or mauve colored flowers; fine for contrast effects. Price, 35 cents.

MALVAVISCUS DRUMMONDI grows two to three feet, heavy green leaves, scarlet flowers all summer; thrifty everywhere and lives "forever"; sometimes called Bishop's Mitre. Price, 35 cents.

MOUNTAIN LAUREL. The beautiful dark-green evergreen that grows in the mountains. Fragrant blue flowers in spring resembling a wisteria. When grown in the nursery it forms a fine root system, which makes it easy to transplant. Fine specimens, carefully dug and packed, 50 cents each; small ones, 25 
cents each. (This is Sophora Secundiflora of botanists. The mountain laurel of the Eastern-Southern States is Kalmia Latifolia.)

PAVONIA (Pavonia lasiopetala). A pretty shrub or bush, two feet in height, that is native in a few locations in Southern Texas. Absolutely hardy, and under ordinary cultivation it is covered all the time during the whole spring, suminer, and fall with bright rosy pink flowers. I believe I am the first to offer it. It is a real treasure for any yard. Try it. 25 cents each.

RAIN LILY (Cooperia pendunculata). The fairly lily of the poets. I'ure white, star-shaped; blooms frequently. Price, 50 cents jer dozen; \$2 per 100 . They can be planted on lawns.

REDBUD (Judas tree). Native, hardy, handsome, early spring bloomer. Two varieties, 25 cents.

STANDING CYPRESS (Gilia Cornapafolia). "Captain's Plume," ammal ancl biennial, two to three feet, foliage like cypress vine; beautiful spikes of coral red flowers. Frost does not hurt them. Small plants, in spring, 50 cents per dozen; $\$ 2.50$ per 100 . They can be planted among shrubs.

SYCAMORE. (See Sliades.)

SUMACH. The Staghorn variety from Nortlı Carolina. The leaves show exquisite autumn colors in red, green and yellow. Price, 35 cents.

SPANISH OAK. Red leaves in autumn. Price, 35 cents to 75 cents.

WILD CHERRY. (See Shades.) Price, 50 cents and 75 cents.

\section{CLIMBING VINES.}

ANTIGONON Leptopus (Rose-on-the-Mountain). A perennial vine with sprays of glowing pink flowers all summer. Bulb.. Price, 50 cents.

A.IPELOPSIS VETCHII (Japan Ivy). Hardy everywhere. Brilliant foliage in fall. 25 cents.

HONEYSUCKLE-EVERGREEN. Fragrant, white and yellow flowers; dense, rank, evergreen foliage; the best for shades or screens. Price, 25 cents.

HONEYSUCKLE-RED CORAL. Coral-red flower; commences to bloom very early. Price, 25 cents.

JAPAN IVY (Ampelopsis Veitchi). Hardy wall creeper. Foliage shows rich shades in the fall. Price, 50 cents.

ENGLISH IVY. Clings to stone, brick or wood. It adds beauty to any building. Price, 25 cents.

TRUMPET CREEPER (Tacoma). Rampant vine that clings to any wall or tree like an ivy; trumpet shaped flowers, three inches long; two varieties, red and yellow. Price, 25 cents.

IVISTERIA. Hardy, woody vine that soon runs 50 feet; fragrant flowers in early spring; purple and white. Price, 25 cents.

\section{SHADES.}

Alnost erery home and every farm needs more shades. Their values can be increased by spending a few dollars for long-lived shade trees, besides the beauty they add to a place and the comfort they give to man and beast, which should be the chicf incentive in planting. My friends, "think on these things."

BLACK LOCUST. Over a large part of the State, and especially in the Panhandle and on the plains, this is one of the most satisfactory shades. I lave a fine lot from 5 to 15 feet worth 5 cents per foot. Some extra fine heavy trees, worth $\$ 1$ each.

BOIS D'ARC. Hardy, long-lived tree, appreciated by many who have them. 5 to 10 feet, 5 cents per foot.

BOX ELDER. A handsome, quick-growing tree; popular in many sections. Price, 4 to 9 feet, 25,35 and 50 cents.

JAPAN CATALPA. Leares larger and trees more healthful than common Catalpa. Price, 5 to 6 feet, 35 cents; 8 to 9 feet, 50 cents.

UMBRELLA CHINA. Quick growing; dense, round top. Price, $3 \frac{1}{2}$ to 4 feet, 25 cents; 4 to 5 feet, 35 cents; 5 to 6 feet. heary, branched, 50 cent-; $7 \frac{1}{2}$ to 8 feet, 75 cents; 8 to 10 feet, $\$ 1$.

WILD CHINA (Sapindus marginatns). A wild tree found in many sections of the State; always healthful, and thrives on all soils; makes a quick shade, and is long lived. Price, 3 to 4 feet, 25 cents; larger sizes, 35 and 50 cents.

COTTONWOOD. A rapid grower on rich land; an ornament on any location. If water be shallow, it makes a mammoth tree, and lives for 150 years. A good windbrake if a row of arbor vitæ or other dense-growing evergreen be planted leside them. Nursery-grown trees are straight and well rooted. Small trees or large ones cheap by the thousand. Price, select, straight specimens, 6 to 7 feet, 35 cents; 8 to 10 feet, 50 cents.

ELM. The long-limbed, fast-growing American Elm is always admired; grows 
well on any ordinary soil. Price, 5 to 6 feet, 35 cents; 8 to 10 feet, 50 cents; 10 to 14 feet, 75 cents.

HACKBERlis. One of the hardiest trees in existence. On poor land or very dry locations it is to be recommended. Young trees, 5 to 10 feet, 5 cents per foot.

JAPAN VARNISH. A stately, hardy, tulip-leaved tree from Japan; smooth, green bark that looks like it was varnished. Price, 3 to 4 feet, 50 eents; 4 to 6 feet, 75 (ents.

I.ITEO.IK. The native evergreen oak. It soon makes a beautiful tree. Wellrooted nursery grown, to 4 feet. Price, 15 cents a foot.

RLSSLA JULBERRY. Nonbearing, grafted. Hardy, long-lived. Price, 7 (ceuts a foot.

MULBERRI. Non-bearing (white or Paper Mulberry). A desirable, longlived shade; free from objections; thrives on poor soil and in dry climates. P'rice, j to (i feet, io cents; (i to s feet, 7 ij cents; 8 to 10 feet, $\$ 1$.

IMPERIAL PAULONIA. A tree from Japan that somewhat resembles a catalpa. Leaves very large, sometimes measuring 22 inches across; panicles of light blue flowers. For tropical effect, eut tree to the ground every spring and let one sprout grow; it will reach 12 to 14 feet in one season. Price, 4 to 6 feet, 50 cents; 8 to 10 fect, 75 cents.

CAROILINA POPLAR. Resembles cottonwood; branches more slender and leaves slightly smaller; a sucessful shade for the dry sections. Should be largely planted. Price, 6 to 7 feet, 25 cents; 7 to 9 feet, 35 cents; large, selected specimens, 50 cents.

LOMIBARDY POPLAR. Graceful, tall, slender; gives fine effect if properly placed on a landscape. Price. 4 to 6 feet, 25 cents; 8 to 10 feet, 50 cents.

SILVER-LEAVED POPLAR. Leaves white on under side, and, when stirred by breeze, the tree seems loaded with white flowers; good for shade or for background in massing shrubs. Price, 4 to 7 feet, 35 and 50 cents.

SPANISH OAK. Native sursery-grown. Hardy shade. Beautiful red leaves in fall. Price, 2 to 7 feet, 10 cants a foot.

SYCAMORE. Although generally found growing along water-courses, it is one of our most reliable and satisfactory shades for all kinds of soils and locations. Price, $t$ to 10 feet. 7 cents a foot.

SYCAMORE. Oriental or Asiatic. Slightly more upright in growth; suits our climate. Price, 4 to 8 feet, 8 cents a foot.

AFRICAN' TAMARIX (Salt Cedar). One of the hardiest trees known. Soft cedar like foliage. Good for small shade and for screens and windbrakes. Price, 3 to 6 feet, 5 cents a foot.

WEEPING WILLOW. At the back of most lawns or landscapes a willow generally gives a pleasing, quiet tone. If a tall, straight body is desired, the leading central branch should be tied to a tall stake the first year or two. Price, 35 cents.

IVILD CHERRY (Prunus Serotina). Grows wild from Austin westward. A beautiful symmetrical tree that responds to cultivation. White flowers in spring. Fruit black of little value. I recommend this tree. Price, 2 to 6 feet, 12 cents a foot.

\section{EVERGREENS.}

These should be planted more extensively all over the prairie and post oak regions of the State. No yard fence is so restful as an evergreen hedge. A row of cheap arbor vitæ around barn lots breaks the winds, and a few dozen arbor vitæ or privets or other evergreens massed in a backyard add to appearances and protect fowls from the sun and winds.

CHINESE ARBOR VITÆ. Fast grower; always green; good for single speeimens or for screeus and windbreaks. I have some 15 feet tall, with straight prured bodies 6 to 8 feet; stately; easy to transplant. Worth $\$ 3$ to $\$ 5$ delivered. Price, small trees, fine selected specimens, 25 cents per foot; common grade, 12 to 20 cents per font.

GOLDEN ARBOR VITE. Compact, even outline; pure green; always a favorite. Fine specimens, 50 cents per foot.

PIRAMIDAL ARBOR VITAE. Symmetrical; upright; elegant form. Price, 40 cents per foct.

ROSEI)ALE ARBOR VITA. A feathery, peagreen, compact tree; greatly admired; a Texas product supposed to be a cross between a Golden Arbor Vitæ and a Japan Cedar. Price, 50 cents per foot.

BOX. An old favorite, glossy leaved, compact. Choice sheared specimens 50 cents per foot.

NATIVE CEDAR. From the mountains northwest of Austin; a handsome tree. Trees that have been transplanted in the nursery have fibrous roots that 
make them quite sure to grow. Price, 1 to 2 feet, 40 cents; wild ones, carefully handled, 10 to 18 inches, $\$ 8$ per 100 .

RED CEDAR. The tall, handsome trees that grow between Austin and the coast. Same price as above.

DEODARA CEDAR. A pale green cedar from the Himalaya Mountains; perfectly suited to our climate; easy to transplant; very graceful. Price, 50 cents per foot.

HORIZONTAL CYPRESS. A dry-land cypress from Italy; tall, straight tree with limbs quite horizontal. Price, 40 cents per foot.

PYRAMIDAL CYPRESS. Slender, tapering form; the Lombardy of evergreens. Price, 40 cents per foot.

EUONYMUS JAPONICA. Very hardy; easy to transplant; round, dark green, glossy leaves; can be sheared into any shape. Price, small for hedges, $\$ 10$ per 100 ; large, selected trees, bushy, 1 to 2 feet, 25,35 and 50 cents.

LIGUSTRUM JAPONICA (Japan Privet). This is the smoother-leaved erergreen, shown so beautifully on the plazas in San Antonio and along the drive in front of our Capitol.

The first that were brought from Japan to Western Mexico are now four feet in diameter with tops 120 feet across. No tree has ever grown faster in public favor, and it is worthy of it. Bright green winter and summer with black berries at Christmas. They can be pruned to a straight stem or left bushy for massing and for screens. Price, pruned or umpruned, 2 to 8 feet, 12 cents a foot.

MAGNOLIA GRANDIFLORA. The large, evergreen; the finest of the Magnolias. Many of them are blooming in Austin. Immense, fragrant, white flowers. Price, 40 cents a foot.

MOUNTAIN LAUREL (See Shrubs). On rich land it grows into a small tree; no more beautiful evergreen. Price, 25 to 50 cents.

AMOOR RIVER PRIVET. Small, bright leaves. Rapid, symmetrical, graceful grower. Profuse white flowers. Fine for specimen trees and for massing. From 2 to 7 feet at from 25 cents to $\$ 1.50$.

\section{FOR HEDGES.}

CALIFORNIA PRIVET. For a quick uniform hedge there may be nothing superior.. These and most hedge plants should be cut within three inches of the ground when planted for best resutls. Price, 1 foot or less, $\$ 3$ a $100 ; 1$ to 2 fett, $\$ 4$ a $100 ; 2$ to 3 feet, with heavy branches, $\$ 5$ a $100 ; 3$ to 4 feet, heary bushy, $\$ 6$ a 100 .

SPANISH RUBY POMEGRANATE. Very attractive; nearly evergreen. Price, $\$ 8$ a 100 .

EUONYIOUS JAPONICA. Evergreen. Price, $\$ 10$ a 100.

ALTHEA. Mixed colors. Price. $\$ 10$ a 100.

CHINESE ARBOR VITA. Every prairie farm should plant a row or double row on north side of barn lots and a grove for chickens. Price, 4 to 6 inch, $\$ 5$ a $100 ; 1$ to 2 feet, $\$ 7.50$ a $100 ; 2$ to 3 feet, $\$ 10$ a $100 ; 3$ to 4 feet. $\$ 12$ a $100 ; 4$ to 5 feet, $\$ 15$ a 100 .

ROSEDALE ARBOR VITL. Price, small 1 year plants, $\$ 10$ a $100 ; 2$ feet, $\$ 25$ a 100 .

RAMSEY HEDGE ROSE. Glossy evergreen; strong growers; lives 50 years. Double pink flowers. Fine windbreak, or can be sheared as desired. $\$ 10$ per 100 .

\section{THE THINGS YOU HAVE NOT HEARD OF.}

This catalogue would be more than double its present size were I to tell you of the many varieties I buy and try and throw away. In order to be sure of having the best I have paid a thousand prices for some new varieties, and then under test find them inferior in some rital quality.

It is to offset in some measure these losses that I charge more for a really valuable new variety when I find it. It is certainly better for the planters to have them tested in this way than for each to plant a lot of worthless varieties.

I am proud of the long list of varieties we have introduced during our thirty years in the business, each of which has proven to be all we have claimed it to be.

If I waited for others to find and judge, and buy and test and advertise new varieties, I could then get buds and grafts and sell at the price of old varieties, possibly one-half or less of the prices of the introducer. I could take his catalogue, show his prices to the people and make some of them believe he was robbing them. Really, now, which of us would you rather patronize? Anything in this catalogue considered solely in the light of an investment is worth several times the price I ask for it. 


\title{
DIRECTIONS FOR PLANTING.
}

When trees are received, if they can not be planted immediately. they should be unpacked. set in a trench. mellow earth thrown around them and thoroughly wet. If trees are frozen when received. the whole bundle should be laid in a trench and entirely covered with earth until the weather moderates. It is best for the ground to be thoroughly plowed before the trees are receired. When it can not be plowed, dig holes eight or ten inches deep, and three or four feet across. When a plow can be used the holes are easily dug by throwing out two or three furrows. and shoveling out the dirt where the trees are to stand. To plant fruit trees, throw in or take out soil until the tree stands the same depth as it did at the nursery; then throw in soil until the roots are covered, and pour in a bucket of water, shaking the tree: then fill in the balance of soil; then cut the tree off from 18 to 24 inches from the ground. Frequent and thorough cultivation with plow and hoe, especially for the first year, is almost absolutely necessary.

To prevent rabbits from injuring young trees, we would suggest that either straw or corn stalks be tied around each tree to a height of about one foot early in fall. Old newspapers will answer the same purpose, and either may be left on during the summer to partly shade the trunks of the trees. This is the only absolutely safe way to protect trees from these pests. Do not make a horse-lot or calf-pasture of your orchard.

\section{DISTANCES FOR PLANTING.}

Standard Apples...

Standard Pears, on Japan roots

Peaches. Plums, Apricots, etc

Blackberries and Dewberries

Strawberries.
20 to 25 feet apart each way 20 to 30 " 16 to 20 " " " " " 2 to $3 \times 5$ " " " " " $2 \times 2$ or $1 \frac{1}{2} \times 3$ " " " "

\section{NUMBER OF TREES OR PLANTS TO THE ACRE.}

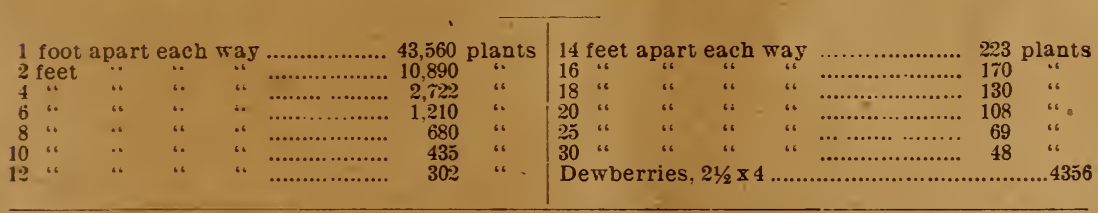

I buy small seedling Peach Seed. No large seed of any kind wanted, as but few will grow. A seed from a grafted or budded tree is as good as any, if it is a variety like the old Spanish or seedling strain of peaches.

You remember the fruit trees that were your favorites when you were a child. Plant an orchard that your children may have the same blessed recollections when they are grown and gone from the old home. You are older and your system does not so keenly crave fruit, but they want it every day. What luxury is so cheap as fresh fruit and berries.

\section{I take pleasure in introducing to our friends and customers the third generation in the management of the nursery.}

My son,

$$
\text { J. M. RAMSEY, }
$$

Having completed his 'studies in our State Uni= versity, will hereafter be associated with me in the nursery business.

\author{
F. T. RAMSEY.
}




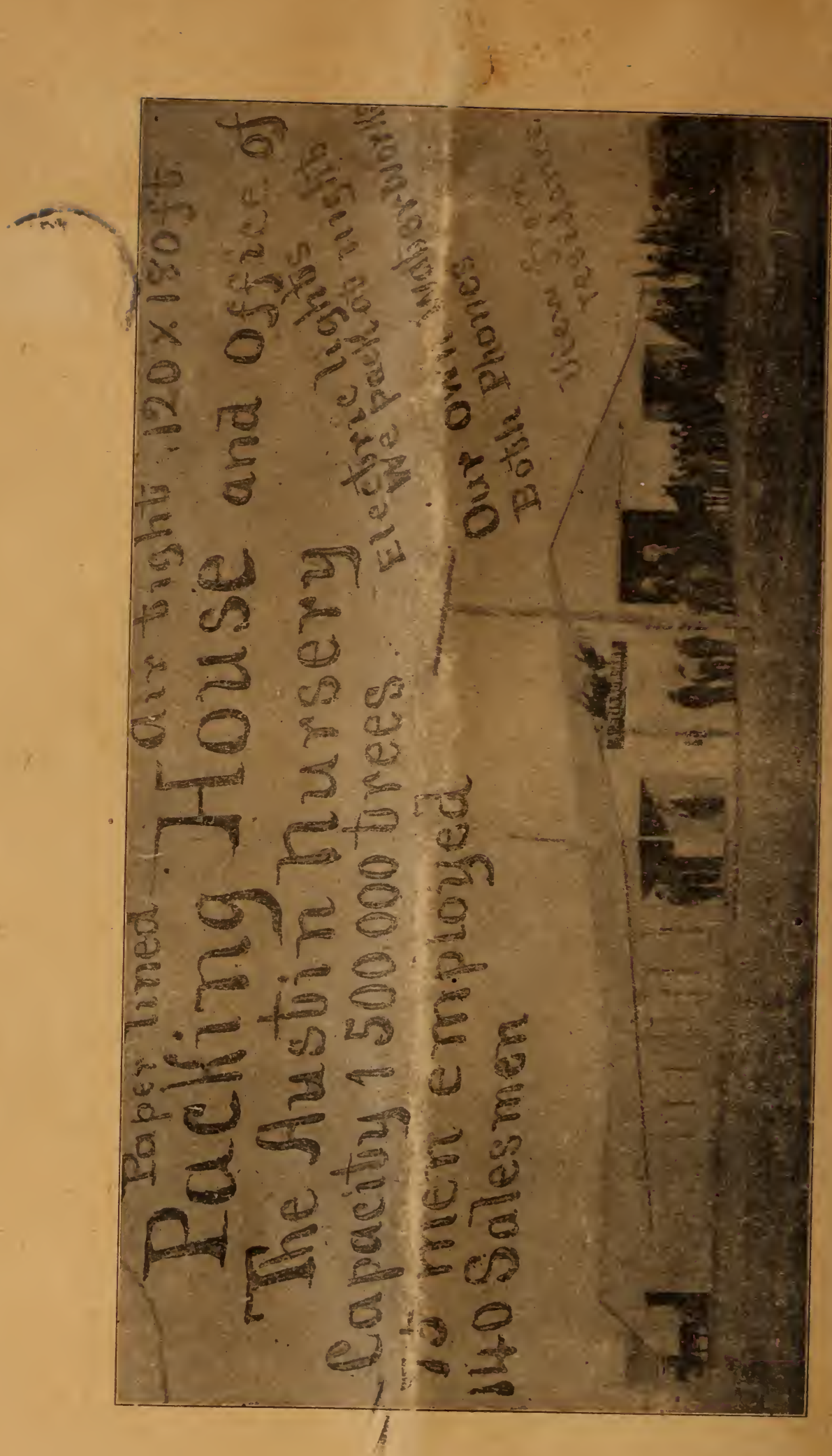

